\title{
Toward a Functional Approach for Managing Complex Litigation
}

\author{
Francis E. McGovern $\dagger$
}

\section{INTRODUCTION}

The managerial horse is out of the judicial barn. Federal Judicial Center ${ }^{1}$ and National Judicial College ${ }^{2}$ programs, the Federal Rules of Civil Procedure, ${ }^{3}$ and the Manual for Complex Litigation

$\uparrow$ Professor of Law, University of Alabama School of Law; Professor, School of Public Health, The University of Alabama at Birmingham; Senior Associate, Program on Negotiation, Harvard Law School; Visiting Professor, Massachusetts Institute of Technology.

The National Science Foundation and the National Institute for Dispute Resolution have provided substantial funding to make it possible for us to develop the litigation management techniques described in the case histories. Many mentors, most notably Judge Sam A. Pointer, Jr., have assisted me in developing my own abilities to devise and implement these procedures. Numerous judges-Alvin B. Rubin, Edward R. Becker, Hubert L. Will; professors-Michael Graetz, Ronald Cass, Wythe Holt, Timothy Hoff; and savants-Edward Hamilton, Francine Rabinowitz, and Deborah R. Hensler-have given most helpful comments to a previous and substantially different draft of this article. James $H$. Davis has been instrumental in developing the footnotes and acting as a sounding board. Barbara St. Clair has done an absolutely superb job of turning a narrative into a law review article. My gratitude goes out to all of these individuals.

1 The Federal Judicial Center was created in 1967 to be the research, development, and training arm of the federal judiciary. 28 U.S.C. $\$ \S 620-629$ (1982) (originally enacted as Act of Dec. 20, 1967, Pub. L. No. 90-210, ch. 42, 81 Stat. 664). Among its assigned duties was "to develop and present for consideration by the Judicial Conference of the United States recommendations for improvement of the administration and management of the courts of the United States." 28 U.S.C. $\$ 620(b)(2)$ (1982). For a description of the Federal Judicial Center and its operations, see Clark, The Federal Judicial Center, 1974 ARIz. St. L.J. 537, 539.

2 Founded in 1964, the National College of the State Judiciary provides in-residence training for trial judges. Cady \& Coe, Education of Judicial Personnel: Coals to Newcastle?, 7 Conn. L. REv. 423, 443-45 (1975). Among its goals is "to encourage the use of the latest techniques to increase court efficiency and improve the quality of justice." Id. at 444 (citing National College of the State Judictary, 1974 Brochure 8,17 (published by the ABA Judicial Administration Division)),

3 For example, rule 16 of the Federal Rules of Civil Procedure has been amended to authorize the use of "special [pretrial] procedures for managing potentially difficult or protracted actions . . . FED. R. Crv. P. 16(c)(10); see VanBebber, Recent Amendments to the Federal Rules of Civil Procedure-Some New Approaches to Case Management and Limits on Discovery in Federal Courts, 52 J. KAN. B. Ass'N 247, 247-50 (1983). Rule 26 was similarly changed to curb problems arising during discovery. See Comment, Making Discovery a Civil Procedure? Proposed Amendments to Rule 26 of the Federal Rules of Civil Procedure, 1982 ARIz. ST. L.J. 725; see also Batista, Sanctioning Attorneys for Discovery Abuse-The Recent Amendments to the Federal Rules of Civil Procedure: Views from the Bench and 
Second ${ }^{4}$ illustrate the significant commitment made by academics and leaders of the judiciary in encouraging judges to become more active litigation managers.

Some thoughtful suggestions have been made, however, that this veritable stampede of judicial management may trample valued aspects of our dispute resolution process. ${ }^{5}$ An increasingly rich academic literature cautions that ad hoc decisionmaking concerning appropriate judicial techniques for overseeing more difficult cases may undermine fundamental procedural fairness. Under this view, decisions concerning procedure should be made ex ante-before a judge is aware of the details of a given lawsuit. If judges engage in ex post applications of procedure, they may imperil our sense of fairness. ${ }^{6}$ Another similar notion cautions that temporary solutions may serve to mask more serious flaws in our dispute resolution methodology which deserve direct attention. Compromise may foster rather than obviate injustice. ${ }^{7}$ Mini solutions may be inappropriate for major problems. ${ }^{8}$

For those of us who have been actively engaged in managing complex litigation, these and other criticisms pose a substantial challenge: to articulate a consistent approach to these cases that copes with perceived problems in our litigation system while maintaining acceptable standards of due process. This paper is the first in a planned series of articles designed to expand the analytic literature describing new case management techniques. ${ }^{9}$ With a suffi-

Bar, 57 St. John's L. Rev. 671 (1983).

1 See Manual for Complex Litigation, Second (1985). See also the original Manual for Complex Litigation (1973) and the following commentaries: Forde, Use of the Manual for Complex Litigation-The Plaintiff's Viewpoint, 15 Forum 137 (1979); Wyllie, Use of the Manual for Complex Litigation-The Defendant's Viewpoint, 15 Forum 163 (1979).

s "If we want judging to be done by judges and only by judges, then we need to institute other changes in addition to increased efficiency. However efficient the judicial branch may become, it cannot mass-produce judges. Wise decisions cannot be made if cases come in vast numbers on a judicial assembly line." Rubin, Bureaucratization of the Federal Courts: The Tension Between Justice and Efficiency, 55 Notre DAME LAw. 645, 656 (1980).

- Ronald Dworkin, A Matter of Princtple 72-103 (1985).

7 See generally Fiss, Against Settlement, 93 YALE L.J. 1073 (1984).

s Comments of Geoffrey R. Hazard, Jr., as panelist on presentation: Summary of Conclusions \& Recommendations, at National Conference on Litigation Management, co-sponsored by Yale Law School, ABA Section on Litigation, and Center for Public Resources, at New Haven, Connecticut, Oct. 3-5, 1985.

- Future articles will consider other cases where the author has been a court appointee in managing complex litigation, such as Wilhoite v. Olin Corporation, where 10,000 named plaintiffs alleged injuries from exposure to a pesticide; Jenkins v. Raymark, a class action involving 750 plaintiffs alleging injuries from exposure to asbestos; and In re A.H. Robins, where over 300,000 claimants alleged injuries from a type of I.U.D. These artiles draw on case study methodology. For discussion of that subject, see Foreman, The Theory of Case 
cient database of case histories, it may be possible by reasoning inductively to develop a functional approach for the judicial management of complex cases.

This article commences with a general discussion of trends in judicial management and alternative dispute resolution techniques. Next a descriptive methodology for analyzing specific cases is proposed, followed by three case histories presented in accordance with the proposed methodology. Each of these histories describes the author's role as an appointee of the court assigned to decide the case. ${ }^{10}$ Finally the article suggests some themes needing further analysis before it is possible to develop a principled approach to complex case management.

\section{A. An Overview of Litigation Management and ADR}

Underlying trends in litigation management and alternative dispute resolution are radical shifts in theories of the relative functions of judges and attorneys. In the classic model of the adversarial process, judges remain passive until the lawyers request their assistance. ${ }^{11}$ The judges are like umpires, ruling on discrete issues raised by the parties; individuals establish a dispute marketplace where state intervention is necessary only when bargaining breaks down.

The new model of the judge's role suggests that dispute resolution should not be left largely to attorneys and parties. Once the state's power is invoked by filing a lawsuit, judges should actively intervene in the administration of justice. ${ }^{12}$ Judges, after all, are expert dispute resolvers: as such they can analyze each dispute, suggest the appropriate methodology for achieving an efficient and

Studies, 26 Soc. Forces 408 (1948); Yin, The Case Study as a Serious Research Strategy, 3 KNOWLEDGE 97 (1981).

${ }^{10}$ In United States v. Michigan, the author served as a special master. In the Alabama utility ratemaking cases, the author was asked by the Supreme Court of Alabama to design a procedure for the use of an appellate expert. In the Ohio asbestos litigation, the author and Professor Eric D. Green of Boston University School of Law were special masters.

"See Fleming James, Crvil Procedure $\$ 1.2$ (1965). In describing the traditional legal process, Professor Chayes noted:

The process is party-initiated and party-controlled. The case is organized and the issues defined by exchanges between the parties. Responsibility for fact development is theirs. The trial judge is a neutral arbiter of their interactions who decides questions of law only if they are put in issue by an appropriate move of a party.

Chayes, The Role of the Judge in Public Law Litigation, 89 HARv. L. REv. 1281, 1283 (1976); see also Frankel, The Search for Truth: An Umpireal View, 123 U. PA. L. REv. 1031, 1042 (1975).

12 See Peckham, The Federal Judge as a Case Manager: The New Role in Guiding a Case from Filing to Disposition, 69 CALIr. L. Rev. 770, 770-71 (1981). 
fair resolution, and monitor the progress of conflicts to ensure that additional intervention is not necessary.

This shift in perception concerning the judge's role arises out of concern that traditional litigation is not functioning satisfactorily for courts, attorneys, parties, and society. ${ }^{13}$ Despite some evidence which shows that a dramatic reduction in case duration may offset increases in the filing rate, ${ }^{14}$ there is a general perception of judicial system overload. ${ }^{15}$ Overworked judges must decide cases hastily, attorneys are compelled both to make and to respond to unjustified demands, parties pay for slower and more expensive decisions, and society suffers under more costly and less wise and legitimate "justice." Most commentators do not conclude that judges are lazy, attorneys greedy, parties enamored of conflict, and society masochistic. Rather, they argue either that people overuse the courts or that traditional dispute resolution methods are obsolete; proposed solutions then take the form either of limiting public use of the judicial system or of making litigation more efficient.

The access limiters suggest increasing filing fees, ${ }^{16}$ reducing substantive rights, ${ }^{17}$ curbing jurisdiction, ${ }^{18}$ and lessening incentives to bring suit. 19 They often view the judicial process as a public

12 See id.; see also Rubin, The Managed Calendar: Some Pragmatic Suggestions About Achieving the Just, Speedy, and Inexpensive Determination of Civil Cases in Federal Courts, 4 Just. Sys. J. 135 (1978); Schwarzer, Managing Civil Litigation: The Trial Judge's Role, 61 Judicatura 400 (1978).

14 See Galenter, Reading the Landscape of Disputes: What We Know and Don't Know (and Think We Know) About Our Allegedly Contentious and Litigious Society, 31 UCLA L. REv. 4, 36 (1983).

${ }^{15}$ See, e.g., JeThro Ligberman, The Litigious Society 8 (1981).

1s See, e.g., Richard Posner, The Fedraral Courts: Crisis and Reform 132-36 (1985) ("Stiff fees ... would tend to divert cases with small monetary stakes from the federal court system to more suitable dispute-resolution processes, since a fixed user fee would constitute a higher percentage tax on such cases than on cases with larger stakes."); Cox, Higher Fees Urged to Pay for Courts, Discourage Suits: Economic Disincentives, L.A. Daily J., Oct. 8, 1981, at 1, col. 2. But see Michelman, The Supreme Court and Litigation Access Fees: The Right to Protect One's Rights (pt. II), 1974 Duks L.J. 527, 560-63 (suggesting constitutional challenges to such fees).

${ }^{27}$ See, e.g., R. PoSNER, supra note 16, at 192-97; see also Reinhardt, Limiting Access to the Federal Courts: Round Up the Usual Victims, 6 WHITTIER L. Rev. 967 (1984).

1s See, e.g., R. PosNer, supra note 16, at 139-47; see also Rowe, Abolishing Diversity Jurisdiction: Positive Side Effects and Potential for Further Reform, 92 HARv. L. REv. 963 (1979). But see Frank, The Case for Diversity Jurisdiction, 16 HaRv. J. on LEgIs. 403 (1979); Marsh, Diversity Jurisdiction: Scapegoat of Overcrowded Federal Courts, 48 BRookLYN L. REv. 197 (1982).

20 See, e.g., Comment, Financial Barriers to Litigation: Attorney Fees and the Problem of Legal Access, 46 ALB. L. REv. 148, 164-65 (1981) (suggesting that adoption of the English rule for allocating costs, including reasonable attorneys' fees, would probably reduce court congestion by penalizing frivolous claims and defenses); see also Rowe, The Legal Theory of Attorney Fee Shifting: A Critical Overview, 1982 DukE L.J. 651; Shavell, Suit, 
good and believe that ease of entry results in overuse. If filing fees, for example, were increased substantially, the marketplace would insure that only the more serious cases had access to the available resources. Another suggested technique for reducing overload is cutting down the number of legally recognized interests. Some commentators have proposed that certain categories of cases, such as personal injury suits, be decided by non-judicial tribunals ${ }^{20}$ or resolved in the marketplace through bargained-for insurance. ${ }^{21}$ In the federal system, some propose easing crowded dockets by eliminating diversity jurisdiction. ${ }^{22}$ Others suggest restricting awards of attorneys' fees by imposing caps ${ }^{23}$ or using the English system of payment of costs. ${ }^{24}$

Needless to say, the more extreme versions of access limitation $^{25}$ have met with less than universal acclaim. Proposals to achieve more efficiency by reducing fundamental legal rights have garnered particular criticism. If society chooses not to hear certain types of cases, some costly effects might be created..$^{26}$

Settlement, and Trial: A Theoretical Analysis Under Alternative Methods for the Allocation of Legal Costs, 11 J. Legar Stud. 55 (1982).

${ }^{20}$ See, e.g., Treiger, Relief for Asbestos Victims: A Legislative Analysis, 20 Harv. J. on LEGIs. 179, 186-200 (1983) (discussing various bills introduced in Congress to provide for an administrative remedy); Soble, $A$ Proposal for the Administrative Compensation of Victims of Toxic Substance Pollution: A Model Act, 14 HARv. J. on LEgIS. 683, 729-59 (1977).

${ }^{21}$ See O'Connell, A "Neo No-Fault" Contract in Lieu of Tort: Preaccident Guarantees of Postaccident Settlement Offers, 73 CaLIF. L. Rev. 898 (1985). See also Professor O'Connell's earlier articles, including Overcoming Legal Barriers to the Transfer of ThirdParty Tort Claims as a Means of Financing First-Party No-Fault Insurance, 58 WASH. U.L.Q. 55 (1980) (with Beck), Financing First-Party No-Fault Insurance by Assignment of Third-Party Tort Claims, 1978 INs. L.J. 207, Harnessing the Liability Lottery: Elective First-Party No-Fault Insurance Financed by Third-Party Tort Claims, 1978 WASH. U.L.Q. 693, and Contracting for No-Fault Liability Insurance Covering Doctors and Hopitals, 36 Mp. L. REv. 553 (1977).

${ }^{22}$ See the articles cited supra note 18.

${ }^{23}$ For a listing of judicially adopted contingent fee schedules and rules, see Rhein, $J u$ dicial Regulation of Contingent Fee Contracts, 48 J. AIR L. \& CoM. 151, 173 n.209 (1982). Similarly, some jurisdictions have limited judgment amounts. See, e.g., Fein v. Permanente Medical Group, 38 Cal. 3d 137, 695 P.2d 665, 211 Cal. Rptr. 368 (approving a \$250,000 limit on non-economic damages in medical malpractice suits), appeal dismissed, $106 \mathrm{~S}$. Ct. 214 (1985); MONT. CoDE ANN. § 27-1-221(6)(b) (1985) (limiting punitive damages in cases not involving fraud or actual malice to the greater of $\$ 25,000$ or $1 \%$ of the defendant's net worth).

24 The English system is "winner take all": the loser has to pay the winner's reasonable attorneys' fees. Richard Jackson, The Machinery of Justice in England 518 (7th ed. 1977). For the practice in other European nations, see Werner Prennigstorr, Legal Expense Insurance: The European Experience in Financing Legal Services 39 (1975).

${ }^{25}$ See, e.g., Hager, Access to Justice: House Panel to Study Whether Courts are the Best Place to Settle Many Disputes, 35 CoNG. Q. WeEkLy ReP. 1229, 1231-32 (1977).

${ }^{28}$ See Fiss, supra note 7, at 1087-88; see also Edwards, Alternative Dispute Resolu- 
Proponents of improving litigation efficiency suggest increasing professionalism in judicial administration and management. ${ }^{27}$ According to this view, judges can engage a broad range of skills and tools to move the litigation pig through the judicial python. They should not be restricted to traditional methods but should be given substantial flexibility to design dispute resolution procedures.

The Alternative Dispute Resolution (ADR) movement also has its origins in dissatisfaction with current litigation. ${ }^{28}$ Supporters of $\mathrm{ADR}$ suggest that disputants consider developing and using less adversarial techniques to resolve their conflicts, and that potential gains in efficiency, ${ }^{29}$ quality, $^{30}$ personalization, ${ }^{31}$ privatization, ${ }^{32}$ and fairness ${ }^{33}$ will result from using non-traditional dispute resolu-

tion: Panacea or Anathema?, 99 HARv. L. REv. 668, 677-78 (1986) ("But surely the mere resolution of a dispute is not proof that the public interest has been served . . . [P]rivate settlements are troubling when we have no assurance that the legislative- or agency-mandated standards have been followed, and when we have no satisfactory explanation as to why there may have been a variance from the rule of law.") (discussing mediated settlement of an environmental dispute).

As an example of costly effects, allowing equal protection challenges to discriminatory actions arguably serves not merely to compensate the victims of discrimination. It also encourages minority group members to strive to break down the barriers of prejudice, by implicitly telling them that society views their efforts as desirable behavior. Without a remedy, not only would the harm of discriminatory treatment remain uncompensated, but the implicit social acceptance of discrimination would discourage minorities from seeking to eradicate prejudice.

${ }^{27}$ See, e.g., Solomon, The Training of Court Managers, 1981 B.Y.U. L. REv. 683; Stott, The Judicial Executive: Toward Greater Congruence in an Emerging Profession, 7 Just. Sys. J. 152 (1982).

${ }^{28}$ See Alternative Dispute Resolution, 29 Vul. L. Rev. 1219 (1984); Alternatives to Litigation, 48 Alb. L. REv. 569 (1984); see also Cover, Dispute Resolution: A Foreword, 88 Yale L.J. 910 (1979); Davis, A New Approach to Resolving Costly Litigation, 61 J. PAT. OpF. Soc'y 482 (1979); Edelman, Institutionalizing Dispute Resolution Alternatives, 9 Just. Sys. J. 134 (1984); Eisenberg, Private Ordering Through Negotiation: Dispute Settlement and Rulemaking, 89 HARv. L. REv. 637 (1976); Staller, The Advantages of Alternative Dispute Resolution in Tort Cases, 31 Practical LAw. 57 (1985).

${ }^{20}$ See, e.g., Aksen, Arbitration of Automobile Accident Cases, 1 Cons. L. Rev. 70, 7887 (1968) (suggesting that an arbitration program expedited payment of claims); see also Note, California's Pilot Project in Economical Litigation, 53 S. CAL. L. REv. 1497 (1980).

so See Cooke, The Highways and Byways of Dispute Resolution, 55 ST. JoHN's L. REv. 611,631 (1981).

32 One criticism of using courts to resolve disputes is that "our court system often precludes direct participation by the principal parties to a dispute, relegating the tasks of communication and negotiation to lawyers and other advocates." Susskind \& Madigan, New Approaches to Resolving Disputes in the Public Sector, 9 Just. Sys. J. 179, 179 (1984).

22 See Christensen, Private Justice: California's General Reference Procedure, 1982 Am. B. Found. Research J. 79, 84; Note, The California Rent-A-Judge Experiment: Constitutional and Policy Considerations of Pay-As-You-Go Courts, 94 HARv. L. REv. 1592, 15991600 (1981).

ss See Institute ror Civil Justice, AN Overview of the First Five Program Years 36 
tion mechanisms. ${ }^{34}$ At the same time ADR proponents often stress the behavioral weaknesses of lawyers as dispute managers. ${ }^{35}$ They argue that attorneys are socialized to be procedurally adept, but not to focus on the fundamental goals of legitimate dispute resolution. ${ }^{36}$ They are more intent on maximizing marginal gains by strategic manipulation of the adversarial process than in insuring that those gains exceed the marginal costs of obtaining them. As a result, disputants receive both inefficient and unsatisfactory "justice."

Both the judicial management and ADR movements posit a model of litigation that deviates from the traditional paradigm of two adversaries following defined rules and needing an official decision. Instead, they assume a great diversity of lawsuits reflecting multiple degrees and causes of conflict, and believe that procedural devices can be tailored to each dispute to foster fair and efficient resolution. ${ }^{37}$ Both movements contend that our stylized adversarial process is inappropriate in many cases. They note that adversarial dispute resolution may solidify the public positions of parties before they have had a genuine opportunity to explore their actual interests. They suggest that disputants can often achieve better results by cooperating in developing information and in determining a resolution, ${ }^{38}$ or by employing a third party to find, or to assist the parties to find, the underlying facts and an appropriate solution..$^{39}$

(1983) (most participants in a court-annexed arbitration program in Pittsburgh believed the outcomes to be fair).

s4 For example, new devices, such as the mini-trial, involve the actual parties jointly in a confirmation-sharing and decisionmaking process that can be relatively inexpensive and yet result in an acceptable decision. See Davis, A New Approach to Resolving Costly Litigation, 61 J. Pat. Ofr. Soc'y 482 (1979); Green, Marks \& Olson, Settling Large Case Litigation: An Alternative Approach, 11 Loy. L.A.L. REv. 493 (1978).

ss Riskin, Mediation and Lawyers, 43 Oнго ST. L.J. 29, 43-51 (1982).

ss $I d$. at 48.

37 Proponents of ADR have suggested the concept of the "multidoor courthouse" where a multitude of techniques would be available, depending upon the nature of the conflict and characteristics of the participants. See S. GoldBerg, E. GreEn \& F. SANDER, Dispute ResoLUTion 514-16 (1985); Sander, Varieties of Dispute Processing, 70 F.R.D. 111 (1976) (conceptual origins of the "multidoor courthouse").

ss "In virtually all cases, the solution that two parties can work out themselves, voluntarily, will be better than the solution that the most Solomonic court could come up with, as the court is limited in the remedies that it can prescribe." Recent Developments in Alternative Forms of Dispute Resolutions (ADR), 100 F.R.D. 512, 514 (1983) (remarks of Professor Eric D. Green).

${ }^{39}$ See Fuller, Mediation-Its Forms and Functions, 44 S. CaL. L. Rev. 305 (1971). A neutral third-party's assessment of a case may offer a more realistic prediction of the trial outcome and may obviate each party's hesitancy to be the first to suggest settlement. Wayne Brazil, Settling Civil. Suits: Litigators' Views About Appropriate Roles and Effective Techniques for Federal Judges 44-46 (1985). 
By interjecting devices to encourage cooperation ${ }^{40}$ or to find facts more inquisitorially ${ }^{11}$ (devices undervalued by existing procedure), the courts, attorneys, and parties may be able to resolve conflict more efficiently and fairly.

Both movements, then, rely upon a theory of dispute resolution that emphasizes flexibility and compromise. ${ }^{42}$ That is not to suggest that the existing system neglects compromise or that compromise is always appropriate; the current system is extremely successful in fostering settlement. Roughly 80 percent of cases filed in the federal courts that receive some judicial treatment actually settle. ${ }^{33}$ The questions, for cases that are appropriate for settlement, are whether litigation management and ADR can increase the percentage of those cases that are settled and reduce the time and effort it takes to resolve them. If this can be done, some disputes that currently require the scarcest resource-judicial trial time-would be resolved by other means. This would free up court time for more efficient allocation to the remaining unsettled cases.

Opposition to the management movement has been expressed on two broad fronts: first, that the existing system works just fine, ${ }^{44}$ and second, that judicial intervention will precipitate a substantial loss in public values, particularly in the absence of any principled mechanism for selecting alternative legal procedures. ${ }^{45}$ Opponents of $A D R$ argue that its fundamental premises are either unrealistic ${ }^{46}$ or actively detrimental to society. ${ }^{47}$ Parties who have (1979).

40 See P.H. Gulliver, Disputes and Negotiations: A Cross-Cultural Perspective 3-7

41 Langbein, The German Advantage in Civil Procedure, 52 U. CHI. L. Rev. 823, 830-32 (1985).

42 R. Goldmann, Introduction to Roundtable Justice: Case Studies in Conflict ResoLution 1, 2 (R. Goldmann ed. 1980).

43 About $90 \%$ of all civil cases are settled privately, see Galanter, supra note 14, at 27, but it must be noted that approximately one-half of all suits are terminated without any court action. Statistics for 1983 show that in the federal district courts $42.4 \%$ of all terminations of diversity cases involved "No Court Action." ADMIN. OfFICE of THE U.S. CouRTs, Federal Judicial Workload Statistics During the Twelve Month Period Ended DecemBER 31, 1983, at A-25 (1984).

44 Cf. Edwards, supra note 26, at 671 (generally agreeing that new approaches to litigation are needed, but cautioning that using ADR procedures where public rights and duties are involved may threaten our constitutional system).

4s See Fiss, supra note 7; Singer, Nonjudicial Dispute Resolution Mechanisms: The Effects on Justice for the Poor, 13 Clearinghouse Rev. 569, 574-76 (1979) (contending that courts equalize power imbalances while ADR maintains relative power positions, thus favoring the "haves").

16 This position has been summarized as follows:

Some commentators, adopting an historical perspective, suggest that the present call for reform is neither novel nor indicative of a real crisis, but is simply the most recent 
less power and society as a whole with its interest in the information that disputes generate will be disadvantaged by private dispute resolution. Powerful parties would not use these procedures unless they redounded to their overall strategic advantage.

Some commentators criticize activist judges for using tactics to stimulate settlement that are tantamount to coercion. Yet proponents of litigation management do not contend that any litigant should be forced to settle or that any given case is susceptible to settlement. ${ }^{48}$ Rather, they believe that a large domain of cases is suitable for and will benefit from intervention by judges, lawyers, or parties.

The Manual for Complex Litigation Second supports judicial assistance in tailoring procedures for complex cases. ${ }^{49}$ The original Manual for Complex Litigation was designed to supplement the Federal Rules of Civil Procedure by prescribing strict guidelines for managing complex cases. It advocated, for example, three waves of discovery pursued sequentially in every case. ${ }^{50}$ The new Manual, however, proposes a different management philosophy. It contains a compendium of procedural devices, described in detail, with comments concerning their strengths and weaknesses. ${ }^{51}$ Each

recurrence of a cyclical pattern of popular dissatisfaction with institutions of justice, which is particularly strong at present in light of increased expectations of the courts and public institutions generally.

Bush, Dispute Resolution Alternatives and the Goals of Civil Justice: Jurisdictional Principles for Process Choice, 1984 WIs. L. REv. 893, 897; see also Cavanagh \& Sarat, Thinking About Courts: Toward and Beyond a Jurisprudence of Judicial Competence, 14 LAW \& Soc'y REv. 371, 375-76 (1980); Engel \& Steele, Civil Cases and Society: Process and Order in Civil Justice System, 1979 AM. B. Found. Research J. 295, 346; Galanter, supra note 14, at 49-51, 69-71; Trubek, Studying Courts in Context, 15 LAw \& Soc'y Rev. 485, 491 (1981).

${ }^{47}$ See Resnik, Managerial Judges, 96 HaRv. L. REv. 374, 426-31 (1982) (threat to impartiality).

18 For example, lawsuits involving differences in fundamental values are the least likely candidates for alternative treatment. One commentator noted:

[T] here are some disputes that cannot be resolved simply by mutual agreement and good faith. It is a fact of political life that many disputes reflect sharply contrasting views about fundamental public values that can never be eliminated by techniques that encourage disputants to "understand" each other . . . . One essential function of law is to reflect the public resolution of such irreconcilable differences; lawmakers are forced to choose among these differing visions of the public good.

Edwards, supra note 26, at 678-79; see also Fiss, supra note 7, at 1082-85.

49 Manual for Complex Litigation, Second $\$ 10$ (1985).

Bo Manual for Complex Litigation $\$ 0.50$ (4th ed. 1977). Although one deviation from this procedure is cited, the Manual warns that it "should not ordinarily be repeated."

${ }^{31}$ For example, one section discusses the desirability of early issue identification and the possibility of bifurcating trials or severing issues for trial. MANUAL For CoMpLEX LiTIGATION, SECOND § 21.632 (1985). Another explains how certain management tools have been applied in specific contexts-antitrust, securities, mass torts. Id. § 33.1 (antitrust cases); id. § 33.2 (mass disasters and other complex torts); id. § 33.3 (securities litigation). 
individual judge or attorney must decide, on a case-by-case basis, when intervention may be desirable and which techniques to use - on which cases. This is a far cry from the original Manual's predetermined rules with universal applicability.

Judges or parties can diagnose the dispute, seek opportunities for cooperation and inquisitorial intervention, tailor procedures to enhance those opportunities, implement them, and monitor their operation. Of course, distinguishing between cases that are and are not appropriate for alternative treatment may be difficult. Other objections may also be raised. The empirical evidence to date offers little support for the theory that judicial management or ADR can reduce docket overload. Some limited studies even suggest that case management and new techniques may have perverse effects on efficiency. ${ }^{\text {22 }}$ Marginal changes made to deal with a much larger problem may produce unsettling effects. ${ }^{53}$ If we deviate from a generally accepted series of procedures, we may create new problems that will undermine the legitimacy of the entire system. Thus, we cannot know ex ante whether judicial management or ADR will ameliorate docket overload.

My thesis is that we need principled methods for distinguishing among cases and that the difficulty and uncertainty of the task should not inhibit experimentation-as long as that experimentation can be accomplished without abandoning shared concepts of due process. ${ }^{.4}$ We will make mistakes along the way; this is not a risk-free enterprise. But the potential benefits-given the alternatives-appear to justify the endeavor.

\section{B. Descriptive Methodology}

There is a general consensus that our courts are overloaded

32 "The effect of the usual procedural reforms ... suggested ... is to increase the productivity of litigation expenditures. The relationship to delay is obscure. An increase in the productivity of evidence will, as we have seen, induce litigants to purchase more of it." Posner, An Economic Approach to Legal Procedure and Judicial Administration, 2 J. LEGAL STUd. 399, 447 (1973).

ss For example, there may be problems in ensuring the accountability of the mediator, see Susskind, Environmental Mediation and the Accountability Problem, 6 VT. L. REv. 1 (1981), or of creating or perpetuating an imbalance of power among the parties, see Lazerson, In the Halls of Justice, the Only Justice is in the Halls, in 1 ThE Polrtics of INroRmaL Justice 119 (R. Abel ed. 1982); Nader, Disputing Without the Force of Law, 88 Yale L.J. 998, 1019-20 (1979); cf. Fisher, Negotiating Power, 27 AM. Behavioral Scientist 149 (1983) (assumes power imbalances, and suggests how a good negotiator manipulates them).

s See Experimentation in the Law: Report of the Federal Judicial Center AdviSORY COMMITTEE ON EXPERIMENTATION IN THE LAW (1981) (pointing out parallel concerns and safeguards in human-subject experimentation by scientists and medical researchers). 
and that judicial intervention may be appropriate to guide cases through the system. The most critical questions, however, are when and how a judge or parties should intervene with nontraditional procedures. The mechanical aspects of prescribing management and alternative devices are relatively easy. The Manual Second contains a comprehensive exposition of ways to manage litigation. In addition, numerous articles have suggested taxonomies of disputes and catalogued hosts of techniques to marry varieties of disputes to alternative procedures. ${ }^{55}$ As comprehensive as a manual or taxonomy may be, however, none has accounted for the full panoply of dispute variables. If courts or parties are going to eschew standardized rules for handling cases, they need principles from which to derive new procedures and a methodology for determining when and how to use them. This article suggests a process which may help identify such principles and develop such a methodology.

At first glance, deciding among procedural alternatives may not appear to raise any complex policy issues. Yet procedures are rarely value-neutral, whether or not we believe that they should be. Any procedure-regardless of the nature of the underlying dispute or the method by which procedures are applied-will affect the outcome of a case. ${ }^{56}$ In the personal injury context, for example, it may make a substantial difference whether all issues are tried together ${ }^{57}$ and whether several cases are tried together. ${ }^{58}$ If a court tries the entire case at once, the plaintiff probably gains from having the fact-finder hear evidence concerning both liability and

ss See, e.g., Fine, Moukad \& Taylor, CPR Working Taxonomy of Alternative Legal Processes (pt. I-IV), Alternatives to the High Cost of Litigation, May 1983, at 9, Alternatives to the High Cost of Litigation, Aug. 1983, at 4, Alternatives to the High Cost of Litigation, Nov. 1983, at 5, Alternatives to the High Cost of Litigation, Dec. 1983, at 5.

so See, e.g., Comment, The Impact of Class Actions on Rule 10b-5, 38 U. CHI. L. Rev. 337, 345-65 (1971) (class actions restrict inquiry into issues involving the conduct of individual class members, such as reliance or in pari delicto, focusing instead on issues of strict liability, such as materiality or the purchase-or-sale requirement).

${ }^{87}$ Bifurcation of the liability and damages issues can potentially prejudice a plaintiff who is partially at fault by forcing him to prove the defendant's negligence twice, at both the liability and the damages stages. Otherwise, he will recover only a token award of apportioned damages. It also can prejudice plaintiffs by reducing the effects of emotion on damage calculation. See Weinstein, Routine Bifurcation of Jury Negligence Trials: An Example of the Questionable Use of Rule Making Power, 14 VAND. L. REv. 831, 831-32, 834-35 (1961).

${ }^{88}$ This potentially confuses jurors because of their inability to isolate information on individual plaintiffs. See Hasman v. G.D. Searle \& Co., 106 F.R.D. 459, 460-61 (E.D. Mich. 1985) (refusing to consolidate the trials of three users of the Copper-7 I.U.D.). 
damages. Bifurcating the case probably favors the defendant; 59 severing an issue such as general causation for separate trial definitely benefits the defendant. ${ }^{60}$ Likewise with consolidation: if the cases of five or ten plaintiffs with the same alleged injuries are consolidated for trial, current wisdom suggests that the plaintiffs will find it easier to prove liability. ${ }^{61}$ The effect of consolidation on damages is less clear. Some experts believe that jurors will tend to average damages, resulting in a lower overall verdict, whereas others suggest that jurors may anchor on either the high or low end of potential damages, resulting in a verdict either higher or lower than an unconsolidated trial should produce. ${ }^{62}$

Since any procedural change affects the outcome of a lawsuit, the question is whether the potential benefits from a change to nontraditional procedures will outweigh the potential losses. Of course, this calculation cannot be made with mathematical purity. Neither efficiency analysis ${ }^{63}$ nor a social welfare calculus ${ }^{64}$ alone will be likely to further this process. We would have to make so many assumptions to cope with uncertainty and with enigmatic ramifications that the result would have been merely an illusion of reality. ${ }^{65}$ Perhaps a functional analysis of diagnosis and prescription is necessary to determine when and how alternative litigation management would be appropriate. Such an analysis could provide some consistency and rationality to decisions among procedural alternatives-permitting experimentation yet curbing the potential

so Surveys have shown that personal injury defendants win a substantially greater proportion of bifurcated trials when the issue of liability is tried first than when the issues of liability and damages are submitted at the same time. See Rosales v. Honda Motor Co., 726 F.2d 259, 261 (5th Cir. 1984) (citing 9 C. Wright \& A. Miller, Federal Practice and ProCEDURE $\& 2390$ (1971)) (percentage of defense victories rose from $42 \%$ to $79 \%$ by bifurcation).

"o "There is a danger that bifurcation may deprive plaintiffs of their legitimate right to place before the jury the circumstances and atmosphere of the entire cause of action ... replacing it with a sterile or laboratory atmosphere in which causation is parted from the reality of the injury." In re Beverly Hills Fire Litigation, 695 F.2d 207, 217 (6th Cir. 1982) (the first issue tried separately was whether "old technology" aluminum branch circuit wiring was the cause-in-fact of the fire).

61 See Kershaw v. Sterling Drug, Inc., 415 F.2d 1009 (5th Cir. 1969).

62 Baker v. Waterman S.S. Corp., 11 F.R.D. 440 (S.D.N.Y. 1951).

os See Efficiency as a Legal Concern, 8 Horstra L. Rev. 485 (1980).

of See Galanter, Why the "Haves" Come Out Ahead: Speculations on the Limits of Legal Change, 9 LAw \& Soc'y REv. 95, 149-51 (1974); see also Abel, Socializing the Legal Profession: Can Redistributing Lawyers' Services Achieve Social Justice?, I Law \& PoL'y Q. 5 (1979); Kidder, The End of the Road? Problems in the Analysis of Disputes, 15 Law \& Soc'y Rev. 717 (1981).

os See, e.g., Markovits, Legal Analysis and the Economic Analysis of Allocative Efficiency, 8 Horstra L. Rev. 811, 891-92 (1980). 
for ad hoc or unprincipled decisionmaking.

This descriptive analysis contains two parts: (1) identifying candidates for alternative treatment and analyzing them to evaluate whether a given prescription of alternative procedures may be worthwhile; and (2) examining the potential benefits and losses from a prescribed alternative approach, and weighing them against traditional approaches in light of established criteria for acceptable legal process.

\section{Defining the Descriptive Analysis}

1. Problem Identification and Diagnosis. Both inertia and substantial startup costs are major deterrents to departing from traditional procedures absent some compelling reason. These predominant incentives to remain with the status quo mean that only cases identified as posing problems of sufficient magnitude will be considered for alternative treatment.

What level of problems should there be before parties or judges consider possible management alternatives? The guidelines for making this decision generally are flexible-a set of criteria and a standard to be met before proceeding. Many problems with litigation are expressed in terms of outcome: ${ }^{66}$ parties question the "wisdom" of the result. But since defining wisdom is so difficult, most analyses tend to focus on the process of deciding rather than the merits of the decision.

The criteria for determining the level to which a problem must rise before intervention is appropriate are typically drawn from due process values. ${ }^{67}$ It is far beyond the scope of this paper to suggest a comprehensive standard of due process. ${ }^{88}$ However, a number of accepted criteria are useful in making procedural decisions. The following list of criteria is not meant to be exclusive or all-inclusive; any decisionmaker may add or subtract at will.

There are interests in economy-the costs to the court, par-

${ }^{68}$ Proponents of abolishing the right to a jury trial in complex civil actions argue that jurors cannot reach a "correct" decision because they are incapable of comprehending the evidence. See, e.g., Comment, Complex Civil Litigation and the Seventh Amendment Right to a Jury Trial, 51 U. CHI. L. REv. 581, 582-83 (1984). Similarly, the debate on punitive damages accelerated as the size of such awards increased. See Owen, Problems in Assessing Funitive Damages Against Manufacturers of Defective Products, 49 U. CHI. L. REv. 1 (1982).

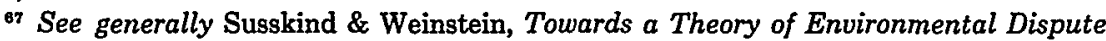
Resolution, 9 B.C. EnvtL. Afr. L. REv. 311, 320 (1980-81).

${ }^{68}$ See generally Francis E. McGovern, Measuring Procedural Change (1986) (unpublished manuscript). 
ties, and society in dollars and time, as well as in errors and opportunity. Much recent attention has been devoted to these concerns and some sophisticated yardsticks have been created to measure them. ${ }^{69}$

Second, there are fairness interests-values of predictability, rationality, and equality of opportunity and strategy. ${ }^{70}$ Arguably decisions concerning legal process should be made ex ante, independent of the details of a given dispute. ${ }^{71}$ Thus the existence of well-defined rules prior to a dispute would curtail the potential for bias against a given party.

Finally, other substantive values concerning appropriate process have been identified-dignity, autonomy, participation, as well as the values informing the applicable substantive law. Proponents of these criteria stress the behavioral side of the dispute resolution process and seek to optimize the effects of alternative procedures. $^{72}$ The criterion that the procedure should promote the values of the applicable substantive law is more difficult to evaluate but is still an arguably important component to any due process analysis. Values in tort law such as deterrence, loss spreading, efficient internalization of costs, punishment, and other behavioral goals of the law are generally acknowledged as critical to any decisions concerning appropriate procedures in personal injury cases. ${ }^{73}$

Once parties or a court have applied their preferred criteria to the problematic aspects of a pending dispute, it is possible to determine whether the perceived problem is related to legal process or not. If the decisionmaker finds fault with traditional procedures and the level of confidence in that decision is high, the case may be considered for alternative treatment. ${ }^{74}$

- See Landes, An Economic Analysis of the Courts, 14 J. LAW \& Econ. 61 (1971); Shavell, supra note 19; Trubeck, Sarat, Felstiner, Kritzer \& Grossman, The Costs of Ordinary Litigation, 31 UCLA L. REv. 72 (1983). See generally Posner, supra note 52 (postulating that the purpose of legal procedure is to minimize the sum of "error costs" and the "direct costs" of operating the legal dispute-resolution machinery).

${ }^{70}$ See J. Thibaut \& L. Walker, Procedural Justice (1975); Walker, Lind \& Thibaut, The Relation Between Procedural and Distributive Justice, 65 VA. L. Rev. 1401 (1979).

71 See supra notes 6-8 and accompanying text.

72 See Jerry Mashaw, Duz Process in the Administrative State 158-253 (1985); Mashaw, Administrative Due Process: The Quest for a Dignitary Theory, 61 B.U.L. Rev. 885 (1981); Summers, Evaluating and Improving Legal Process-A Plea for "Process Values," 60 Cornel. L. Rev. 1 (1974).

7s See Owen, Rethinking the Policies of Strict Products Liability, 33 VAND. L. REv. 681 (1980).

74 Confidence in the need for alternative procedures should exceed a "preponderance of the evidence" standard. The opportunity costs are sufficiently great that "clear and convincing" or "no reasonable persons would disagree" standards are more equitable. For an exam- 
2. Prescription. Next we must examine what impediments to dispute resolution are created by existing procedures and what more desirable procedural variations, if any, would alleviate the problem. This phase of the descriptive analysis draws heavily upon recent analyses of negotiation, ${ }^{75}$ which focus on locating opportunities for a bargained resolution to determine whether the potential for compromise is genuine or illusory. ${ }^{78}$ Under one approach to negotiation, the decisionmakers examine at least three sets of variables to determine if a negotiated result is feasible: the appropriate parties, the potential issues for discussion, and the information sufficient to determine a resolution. Each of these variables is manipulable and can be organized or reorganized to enhance settlement potential. By examining the alternative mechanisms for dealing with parties, issues, and information, the decisionmaker can estimate the probability that nontraditional litigation management will bring about a more satisfactory outcome.

If a party desires to buy a plot of land, for example, but is concerned about the future development of an adjacent parcel, the buyer and seller may be unable to agree on a price because the buyer is discounting the land's value by the probability of unwanted adjacent development. Adding a party may help: bringing the owner of the adjacent parcel into the negotiations might lead to a development plan for both parcels that would financially benefit all three parties.

Adding or subtracting issues may also assist in finding a negotiated result. Politicians intractably opposed on a given issue may be able to resolve their differences by trading votes on additional issues. Agreeing to disagree on certain issues while resolving others is another example of how organizing issues may lead to negotiated outcomes.

Finally, one can add information about values as well as facts. Under so-called differences orientation, information concerning fundamental values and how the parties view risk, time, and probabilities of future outcomes may be critical in reaching a negotiated outcome. ${ }^{77}$ If one party values an immediate return on capital and doubts that the future will bring significant profits, while

ple of the costs of alternative procedures, see infra notes 155-57 and accompanying text.

75 John Cross, The Economics of Bargaining (1965).

76 See, e.g., Robert Axelrod, The Evolution of Cooperation (1984); S. Bacharach \& E. Lawler, Bargaining (1981); Howard Ratrfa, The Art and Science of Negotiation (1982); Anatol Rapoport, Fights, Games and Debates (1960); J. Rubin \& B. Brown, The Soctal Psychology of Bargaining and Negotiation (1975).

77 See James Sebenius, Negotiating the Law op the Sea 114 (1984). 
another party is willing to defer immediate payment in anticipation of future gains, they should be able to bargain. ${ }^{78}$

The Federal Rules of Civil Procedure already recognize these variables. Joinder, ${ }^{79}$ consolidation, ${ }^{80}$ multi-district litigation, ${ }^{81}$ class actions, ${ }^{82}$ and third-party actions ${ }^{83}$ all seek the most appropriate combination of parties for adjudication. Issues can be reordered through bifurcation, ${ }^{84}$ severance, ${ }^{85}$ interlocutory appeal, ${ }^{86}$ and certification. $^{87}$ Most courts use rules 16 and $26^{88}$ and various local rules $^{89}$ to limit or expand discovery to insure that parties provide information at an appropriate level and time.

3. Evaluating Proposed Alternative Procedures. The final phase of the descriptive analysis involves examining a series of comparative judgments using the defined due process criteria, such as the previously suggested economy, fairness, and other substantive values. First, assess the potential benefits from using alternative procedures to solve the identified problem. Savings in time and money, for example, as well as gains in dignity and participation can be roughly estimated. These benefits should then be discounted by the probability that they would not occur. Next, consider any negative externalities from using an alternative methodology, discounted by the probability that they would not occur. When changing a procedure that one party may have relied upon, for example, take into account the chance of affecting the equality of the process. Then, similarly calculate net benefits as-

78 Id. at 119 (presenting two examples: (1) sale of investment property-buyer believes the price will rise while seller assumes it will drop, and (2) performer's contract when the size of the potential audience is uncertain-performer, expecting a huge crowd, may accept smaller guaranteed fee plus a percentage of the gate, which is acceptable to the promoter who assumes a low turnout); see also id. at 132-33.

79 Fed. R. Crv. P. 13(h).

${ }^{s 0}$ Fed. R. Crv. P. 42(a); 28 U.S.C. $\$ 1404$ (1982).

2128 U.S.C. $\S 1407$ (1982).

as Fed. R. Crv. P. 23.

as FED. R. CIv. P. 14.

${ }^{34}$ Fed. R. CIv. P. 42(b).

ss Id.

s6 28 U.S.C. § 1292(b) (1982).

${ }^{87}$ FED. R. Crv. P. 23(c)(4)(A).

ss See, e.g., Flegal, Discovery Abuse: Causes, Effects, and Reform, 3 Rev. Litigation 1, 39-47 (1982); Kaminsky, Proposed Federal Discovery Rules for Complex Civil Litigation, 48 Fordham L. Rev. 907, 912-13 (1980); Comment, Sanctions Under Amended Rule 26-Scalpel or Meat-ax? The 1983 Amendments to the Federal Rules of Civil Procedure, 46 OHo ST. L.J. 183 (1985).

8s See Kahn, Local Pretrial Rules in Federal Court, 6 Litigation, Spring 1980, at 34; see also Flanders, Local Rules in Federal District Courts: Usurpation, Legislation, or Information?, 14 LoY. L.A.L. REv. 213, 227-29 (1981). 
suming the traditional procedure were used, and compare the results. If it appears that the alternative methodology is superior to the existing system, intervention is appropriate.

To summarize, the "when" and "how" of alternative procedures can be decided by identifying the problem, diagnosing its causes, devising techniques to vary the grouping of parties, issues, and information, and weighing the relative merits of traditional and nontraditional approaches using defined due process criteria. In the event that some litigation management or ADR procedure is employed, it should be carefully monitored with frequent feedback. A significant imbalance in expectations might warrant a return to old procedures. Finally, when the dispute has ended, the new process should be extensively evaluated. If society is to benefit from novel approaches, we need full documentation of the procedure as well as an objective analysis of its assets and weaknesses.

The discussion of the following three lawsuits illustrates this descriptive analysis in practice.$^{90}$ Each case contains at least one procedural innovation which has been subject to some level of evaluation.

\section{Allocation of Scarce Resources: Who OWNS the Great LAKES?}

\section{A. Problem}

In 1979 Judge Fox of the Eastern District of Michigan ruled that the Treaty of 1836 between the United States and the Ottawa and Chippewa peoples reserved to the tribes the right to fish in the treaty waters of the Great Lakes unfettered by regulation by the State of Michigan.91 The U.S. Department of the Interior subse-

$0 \mathrm{My}$ editors and I engaged in a substantial debate regarding the use of the third person in the following case histories. They correctly point out that I may run the risk of deluding or confusing the reader concerning my role in these cases, or of appearing to take refuge behind a façade of purported neutrality to my topic. On the other hand, it is my strong feeling that the tone generated by the use of the first person suggests an imperial status that is inconsistent with my perceived role as a cooperative participant in any dispute resolution process. Over their objections, therefore, you will find me described as "special master," "professor," or "we" (when referring to actions taken in conjunction with another special master) in the remainder of the article.

${ }^{91}$ United States v. Michigan, 471 F. Supp. 192 (W.D. Mich. 1979), remanded, 623 F.2d 448 (6th Cir. 1980), as modified, 653 F.2d 277, cert. denied, 454 U.S. 1124 (1981). The progress of the case after Judge Fox's original opinion is somewhat convoluted. The Sixth Circuit stayed his order on September 26, 1979, and remanded for consideration of the preemptive effect of new federal regulations. $623 \mathrm{~F} .2 \mathrm{~d}$ at 449-50. Before the decision on remand occurred, the regulations expired, and the State of Michigan filed an emergency motion with the Sixth Circuit to set aside the remand order and to implement the state's new regulation. 
quently ceased regulating Great Lakes fishing, leaving two independent sovereigns to govern a common natural resource. ${ }^{92}$ The tribal commercial fishers and other Michigan commercial and sport fishers competed for fish in most of the Michigan waters of Lakes Superior, Huron, and Michigan.

This competition triggered significant resource depletion and violence among the competitors. In an attempt to save the basic stocks of fish, the tribes, the state, and the United States agreed to close the fishery each year as soon as a certain amount of fish had been caught. As the competition increased, closure occurred earlier and earlier each year, and the tribes took a smaller and smaller percentage of the catch. The tribes could not compete technologically with the state commercial fishers, nor were they numerous enough to compete with the burgeoning state sport fishers. ${ }^{93}$

As a result of the reduced catch and threats of violence, the tribes moved Judge Fox's successor, Judge Enslen, to allocate the treaty waters between the tribes and the state. ${ }^{94} \mathrm{~A}$ literal reading of Judge Fox's original opinion supported the tribes' view that they had a primary right to the resource and thus should be able to take whatever fish were necessary to maintain reasonable tribal living standards. Given the tribes' depressed economic state, they might obtain a virtual monopoly on Great Lakes fish stocks. The State of Michigan countered that any allocation should be made on

See United States v. Michigan, 520 F. Supp. 207, 209-10 (W.D. Mich. 1981), aff'd, 712 F.2d 242 (6th Cir. 1983). The Sixth Circuit ruled that in the absence of federal regulation, the State could regulate Indian fishing only if it met certain stringent criteria; the court retained the federal regulations as interim rules until modified by the district court. 653 F.2d at 278-79. On remand, Judge Fox dismissed the action, noting that the preemption question was moot, that the state had no intention of fulfilling the Sixth Circuit's criteria for regulation, and that the tribes had adopted as internal law the lapsed federal regulations. $520 \mathrm{~F}$. Supp. at 210-11 \& n.4.

92 At the time of Judge Fox's ruling, the Indians fished under regulations promulgated by the Secretary of the Interior in 1967, 25 C.F.R. $\$ 256$ (1968), and their own tribal regulations, enacted subject to Interior Department review. After the ruling was appealed and the Sixth Circuit stayed Judge Fox's injunctions, the Secretary of the Interior promulgated a new set of regulations, 44 FED. REG. 65,747 (1979), as amended, 45 FED. REG. 28,100 (1980) (codified at 25 C.F.R. § 256 Subpart D (1981)), which were allowed to expire on May 11, 1981. See 520 F. Supp. at 209. The Secretary of the Interior retained the right to promulgate regulations, and the State of Michigan had the right to regulate the Indians if it could make a proper showing. Id.; see supra note 91.

83 For background, see C. Cleland \& R. Bishop, An Assessment of the Economic Conditions of the Bay Mills Indian Community, Sault St. Marie Tribe of Chippewa INdians, and Grand Traverse Band of Ottawa and Chippewa Indians, and a Cost-Return Analysis of Treaty Commercial Fishermen-1981 (1984). The Indians relied mainly on gill nets which require only a small boat and almost no machinery.

" Indian Tribes' Amended Motion to Allocate Resource, United States v. Michigan, Civil Action No. M26-73 (W.D. Mich. Apr. 25, 1984). 
equitable grounds, taking into account not only the tribes' subsistence needs but also how best to maximize the fishery's potential economic benefits to all Michigan citizens. Because sports fishing generated far more direct and indirect income than tribal fishing, an economic analysis would tilt the scales toward control of the fishery by Michigan sports fishers. The United States argued for a 50-50 split between the tribes and the state. The treaty itself contained little guidance for resolving the allocation issue. ${ }^{95}$

Given the paucity of precedent for any allocation scheme, the parties' wildly differing approaches, the extreme volatility of the situation, the complexity of any allocation process, and institutional weaknesses associated with continuing judicial management, Judge Enslen decided that if allocation was appropriate, the parties preferably should do it. ${ }^{98} \mathrm{He}$ also believed that an expeditious decision was necessary to minimize the potential for violence in the uncertain situation. Judge Enslen appointed a special master to prepare the case for trial within eight months and explore the possibilities for settlement. ${ }^{27}$ The master's duties did not include ruling on substantive issues, and all his decisions were subject to de novo review by the judge.

\section{B. Diagnosis}

United States $v$. Michigan was relatively complex litigation; the five named parties represented virtually all Michigan citizens. The issues and information involved every conceivable problem associated with managing the largest lakes in the world. From one perspective the case was a generic conflict-a distributional dis-

95 It provided only that "the Ottawa and Chippewa peoples shall have the right to fish in the ceded waters until settlement." In the Treaty of March 28, 1836, the Indians retained "the fishing grounds in front of such reservations [assigned to them]." 7 Stat. 491, 491 (1836). In a separate article, they "stipulate[d] for the right of hunting on the lands ceded, with the other usual privileges of occupancy, until the land is required for settlement." Id. at 495 . In 1855 , this treaty was modified as to the land to be held by the Indians. 11 Stat. 621 (1855).

In addition to the allocation problem, the Indians' use of gill nets necessitated interpretation of the treaties. This method of fishing was widely employed by the Indians when the treaties were signed, and it was contended that the treaties entitled the tribes to use traditional means of fishing and hunting. The sportsmen objected because, unlike newer commercial fishing techniques, the nets ensnared both commercial and sports fish.

96 Judge Enslen observed that "the public interest in a peaceful, and practically enforceable resolution of this matter mandates as preferable a resolution by settlement rather than trial." Order of Reference 2, United States v. Michigan, Civil Action No. M26-73 (W.D. Mich. Sept. 28, 1984).

97 Id. at 3. 
pute to divide a common pool among competing users. ${ }^{98}$ Large numbers of equally situated parties, the fishers, had similar incentives to use a common asset, the Great Lakes, as much as possible. Without intervention, the cumulative use would destroy the resource through massive overfishing. The essential problem was to determine what kind of intervention would help to resolve the dispute.

Under this view of the lawsuit, its big issues were polycentric, not susceptible to the yes-or-no answers or mutually exclusive inquiries typical of special interrogatories posed to juries. ${ }^{99}$ The solution to any given question concerning resource division was dependent upon the solutions reached on the other questions: no issues were independent. This complex interrelationship of issues created difficulties which were compounded by the lack of any-much less clear-legal standards. The court was being asked to make extremely complex management decisions by using policy differences unreflected in the substantive law- "reasonable living standards," "subsistence," "maximizing value," and "equal distribution." Because of the continuing relationship among the parties, any courtimposed solution would probably generate future conflict. Even under optimal conditions, changes in the resource itself would breed future controversies.

Judge Enslen concluded that these characteristics begged for an allocation plan developed by the parties themselves. It was a classic case for integrative bargaining. ${ }^{100}$ The parties could identify their respective interests, share information concerning how they valued those interests, and reach for a combination of trade-offs that would maximize each side's use of the resource. Under an eco-

9s See Ostrom \& Ostrom, A Theory for Institutional Analysis of Common Pool Problems, in Managing the Commons 157 (G. Hardin \& J. Baden eds. 1977); Edney, Paradox on the Commons: Scarcity and the Problems of Equality, 9 J. Community Psychology 3 (1981).

99 See Fuller, The Forms and Limits of Adjudication, 92 HARv. L. Rkv. 353, 394-404 (1978).

100 "An agreement is said to be more 'integrative' the greater its joint utility, that is, the more valuable it is to the two bargainers taken together." Pruitt \& Lewis, Development of Integrative Solutions in Bilateral Negotiation, $31 \mathrm{~J}$. Personality \& Soc. Psychology 621, 621 (1975). The concept has also been described as follows:

Integrative bargaining is the process whereby negotiators attempt to find a settlement that reconciles or "integrates" the needs of both parties. [It] is feasible when the joint payoff from a settlement is not constant across all possible settlements and the negotiators [cannot] initially [identify] a mutually acceptable settlement that will maximize joint payoff.

Yukl, Malone, Hayslip \& Pamin, The Effects of Time Pressure and Issue Settlement Order on Integrative Bargaining, 39 SOcIOMETRY 277, 277 (1976). 
nomic analysis of integrative bargains, they could seek superior allocations, reduce conflicts of interest, and possibly achieve an optimal solution. ${ }^{101}$ Given constraints on a court's ability to gather and evaluate this type of information, the parties would be in a superior position to locate an optimal allocation plan. A party-developed plan would also eliminate any dislocation that could accompany a court-ordered resolution.

However, this diagnosis posed two major problems. First, the parties asserted that the case involved fundamental political values not subject to compromise. Leaders on both sides had invested substantial political capital in their incompatible positions and had constructed arguments slicing to the core of the relationship between two sovereigns in the United States. ${ }^{102}$ Second, these political leaders had attempted to achieve a negotiated resolution on numerous occasions over the years. Thus major behavioral impediments had arisen from personal animosities and low expectations of reaching satisfactory agreement. ${ }^{103}$ The tribal leaders, in particular, had witnessed a long history of negotiation that had not brought prosperity to their peoples. If the behavioral and valueladen components of the lawsuit predominated, judicial resolution was almost inevitable.

\section{Prescription}

Given the apparently great likelihood of a litigated resolution but also significant potential benefits from negotiation, the master implemented both prongs of the judge's order: preparing the case for trial and assisting settlement efforts. Primary importance was given to pretrial development. An expedited discovery schedule was issued to ready the case for trial in four months. ${ }^{104}$ Because massive amounts of information needed to be gathered, the sched-

101 See J. SEBEnIUS, supra note 77, at 115-16.

${ }^{202}$ For a history of the conflict, see Robert Doherty, Troubled Waters: The Political Economy of Treaty-Right Fishing in Michigan's Great Lakes (1985) (unpublished manuscript).

${ }^{103}$ Several previous attempts to reach a negotiated resolution had failed. Talks begun in early 1982 broke down when the parties could not agree on a plan for dividing rights in Grand Traverse Bay; each side accused the other of bargaining in bad faith. After three days of negotiation in August 1982, representatives of the state and the three fishing tribes reached an agreement "in principle," but within a week the agreement began to break down because of tensions between the representatives and their constituents. Again in 1983 there were hopes of a negotiated solution, but the representatives were unable to draft a formal document acceptable to the principals.

${ }^{104}$ Letter from Francis E. McGovern to Judge Richard A. Enslen (Jan. 31, 1985) (outlining discovery schedule) (copy on file with The University of Chicago Law Review). 
ule included several abbreviated forms of discovery and substantial sharing of information.

The negotiation prong was more difficult-insuring that the parties could reach agreement if they chose, without coercing them into a settlement. The initial negotiation strategy borrowed from final offer arbitration. ${ }^{105}$ It contemplated that each party would prepare an allocation scheme for the court. Since the special master would meet ex parte to explore negotiation possibilities with the parties and would thus discover their real interests (as opposed to their litigation-generated positions), he would also recommend an allocation plan. Presumably his plan would be more acceptable to all sides, and could be used either for negotiations or as a mandated resolution to the dispute. Upon further analysis, however, this strategy was fundamentally flawed: because the parties themselves would not develop the plan, its implementation would have the same weaknesses as any court-ordered result. The strategy was changed, therefore, to focus on assisting the parties to develop their own allocation plans in accordance with classic integrative bargaining. This was a higher-risk strategy but, if successful, would have substantially more potential for legitimacy and longevity.

The first task was to determine the likelihood of success for any bargain at all. In conjunction with the Program on Negotiation at Harvard, the master attempted to develop a scorable game that would mimic the actual dispute. ${ }^{108}$ The task involved identifying each party's interests, selecting all feasible elements to any allocation plan, stating the parties' priorities, and determining the variety of systems that could be used to organize those interests and elements. Each priority was then quantified in regard to each issue. The negotiation theory applied to the game was so-called differ-

${ }^{108}$ For general background, see Chelius \& Dworkin, An Economic Analysis of FinalOffer Arbitration as a Conflict Resolution Device, 24 J. Conzlct Resolution 293 (1980); see also Farber, An Analysis of Final-Offer Arbitration, 24 J. Conplict Rzsolution 683 (1980).

${ }^{100}$ The game was entitled "Lake Wasota Fishing Rights Game." "Games can sensitize decision makers to unexpected outcomes while permitting complicated processes to be studied in controlled environments." Herbert RuBin, Applied Social ReSEarch 236 (1983). For discussions of the educational value of such games, see generally Bredemeier \& Greenblat, The Educational Effectiveness of Simulation Games: A Synthesis of Findings, 12 SimulaTION \& Games 307 (1981); Glenn, Gregg \& Tipple, Using Role-Play Activities to Teach Problem Solving: Three Teaching Strategies, 13 Simulation \& Games 199 (1982); Hunsaker, Whitney \& Hunsaker, Learning Negotiation Skills Through Simulation, 14 SimuLATION \& GAMES 391 (1983). 
ences orientation. ${ }^{107}$ For example, each party might value the same portion of Lake Michigan differently. The tribes living in the northern Michigan peninsula would probably prefer unlimited access to waters close to their homes. In contrast, the sports fishers generally lived in southern Michigan and would value the southern waters more highly. Differences orientation was particularly valuable here because of the economic and cultural disparities among the parties: what appeared in the litigation context to be a major problem of fundamental value differences was actually an asset in developing a mutually acceptable allocation plan. Once relative differences had been identified, they were entered into a computer.

A program was run to determine if any scenario would satisfy each party's minimum priorities. When the game was limited to the case's legal issues, no negotiated outcome seemed possible. If, however, the issues were expanded to include other items that might be subject to negotiation, some solutions might satisfy the hypothetical minimum interests of the parties. A court, for example, was limited to interpreting the treaty in perpetuity; an agreement by the parties could be for a term of years. A negotiated disposition, unlike a typical court decision, could also include provisions for plantings of fish, monetary payments, and market development. When these and other issues were added to the computer, there emerged combinations of components which indicated different possible solutions where agreement was feasible.

As originally designed, the scorable game had another, more important function. Its primary purpose was as an educational tool, not just to provide specific answers, but to teach the parties how to negotiate. If all of the key decisionmakers could play the game, typically separately, they might better appreciate their own and their adversaries' positions. Moreover, they might develop more confidence in their own abilities and power as negotiators. The negotiation prong thus became an educational and behavioral task, aimed at educating the parties concerning the potential for maximizing their own interests, developing their strategic negotiating capacity, expanding the roster of issues subject to bargaining, and softening communication and behavioral barriers to face-toface negotiation.

1. Parties. The plaintiffs consisted of three Indian tribes and the United States; the defendant was the State of Michigan. The tribes had extremely varying interests: one tribe desired to perpet-

${ }^{103}$ See J. SEBEnIUS, supra note 77 , at 113-81. 
uate the traditional cultural values of Indian fishing, another desired to maximize the tribes' overall economic benefit, and the third valued accommodation consistent with limited tribal fishing in one area of Lake Michigan. The United States represented the tribal interests and the concerns of the Fish and Wildlife Service in restoring the Great Lakes to their earlier economic prosperity-goals that were not always consistent.

The State of Michigan also represented competing interests: those of state commercial fishers, the developing sports fishing and tourist industry, Indian citizens of Michigan living outside the reservations, and the public peace. The state's prime mover was its Department of Natural Resources, but the organized commercial and sports fishers were independent, politically powerful constituents. Judge Enslen decided, therefore, to bring these groups of state fishers into the litigation, but without full party status. $\mathrm{He}$ named them litigating amici: ${ }^{108}$ they had a participatory role in discovery and at trial, but could not veto a potential settlement. This innovative organization of parties ensured that all the key decisionmakers were present in the litigation.

The court then assigned the special master to mediate among the named parties and the litigating amici. Because the case would eventually be tried to the judge, his ability to facilitate negotiation was limited by his strong ethical constraints against prejudging the outcome of the case. Therefore, the master performed this role while insulating the judge from the details of any bargaining. As a part of the mediation role, the master also kept the parties' critical decisionmakers aware of the progress of the litigation and the negotiations. He met with the leaders and sometimes virtually all the members of the tribes, officials of the U.S. Department of the Interior, and Michigan's Governor, Attorney General, and the Director of its Department of Natural Resources.

2. Issues. The issues were both simplified and expanded. The resource allocation was narrowed to involve five major variables: species of fish, quantity of fish, fishing gear, geography, and time. Even with this gross simplification, a virtually infinite number of combinations of variables and numerous measuring criteria still remained. The parties were asked to narrow these issues further by proposing management plans that they would support at trial.

${ }^{108}$ The litigating amici were the Michigan United Conservation Clubs, the Grand Traverse Area Sport Fishing Association, the Michigan Steelhead and Salmon Fishermen's Association, the Michigan Charter Boat Association, and a large group of individually named, state-licensed commercial fisherman. 
Timing became important in setting the deadlines for identifying plans, because a party might lock itself into a given negotiating posture by solidifying behind a single management plan.

While the parties were narrowing issues, an intensive educational effort was undertaken to broaden the horizons to include additional issues suitable for negotiation. All the parties were questioned in great detail concerning their interests-some totally unrelated to the case-to see if they might be interested in placing them on the bargaining table.

3. Information. Normal discovery had been expedited somewhat by the parties' agreement to pool data concerning Great Lakes fishing. A tripartite group of biologists from the tribes, the state, and the United States had cooperated in developing consensus recommendations based upon shared information. ${ }^{109}$ In addition, the tribes turned over all of their fish catch reports to the state so that the data could be computerized and made available to everyone.

Early in the lawsuit it had appeared that disagreements among the biologists would constitute a major portion of the evidence during trial. Some thought was given to appointing an expert to assist in resolving scientific issues. Because the biologists were cooperating in some areas, however, they were asked if they could develop a joint computer model of the five critical variables. If this could be done, computer runs could be made for each suggested management plan to determine the effects of that plan on these variables. A neutral expert in modeling was asked to assist the biologists and the special master in creating the computer model.

This process has been called computer-assisted negotiation. ${ }^{110}$ Experts attempt to create a consensus model of a complex phenomenon that will, in effect, constitute a negotiated dispute resolution or enable the policymakers to negotiate a result. The created model then scrutinizes hypothetical solutions to verify that any chosen solution can meet parties' expectations.

${ }^{109}$ See Status of the Fishery Resource-1984, A Report by the Tripartite Technical Working Group on the Assessment of Major Fish Stocks in Treaty Ceded Waters of the Upper Great Lakes: State of Michigan (the three parties were the Great Lakes Fishery Laboratory of the United States Fish and Wildlife Service of the U.S. Department of the Interior, the Fisheries Division of the Michigan Department of Natural Resources, and the Chippewa/Ottawa Treaty Fishery Management Authority) (copy available from the author).

${ }_{110}$ See generally Sebenius, The Computer as Mediator: Law of the Sea and Beyond, 1 J. Poz'y ANALysis \& MGMT. 77 (1981) (computer models can "foster learning, help define the negotiating agenda, stimulate communication, and suggest joint gains"). 
In this situation the computer-assisted negotiation was enormously successful, but for a different reason. Negotiations over the model soon revealed that the biologists were generally in agreement, except in areas of massive uncertainty or where basic policy choices were involved. Thus the major by-product of developing this model was to resolve most of the case's biological issues.

Finally, information was added to the lawsuit concerning parallel litigation over Indian salmon fishing rights in the Pacific Northwest. In United States $v$. Washington, ${ }^{111}$ various tribes won a share of the Washington salmon catch. The parties had declined to negotiate a solution to their allocation dilemma, and years of intense litigation ensued. ${ }^{112}$ Representatives of several parties to that case were invited to speak to the participants in United States $v$. Michigan concerning the court's management of their resource. They reported in detail how the court made decisions-even on a fish-by-fish basis-and how fishery managers and fishers coped with these decisions. They also recounted some of the spillovers to tribal relations that had developed out of the case. They generally recommended that a negotiated management plan-if feasible-was preferable to a litigated one. ${ }^{113}$

\section{Results}

After three days of negotiations the parties reached a settlement on March 28, four weeks before the scheduled trial. ${ }^{114}$ The settlement agreement closely paralleled one of the scorable game

11 See United States v. Washington, 384 F. Supp. 312 (W.D. Wash. 1974), aff'd, 520 F.2d 676 (9th Cir. 1975), cert. denied, 423 U.S. 1086 (1976); see also Washington v. Washington State Commercial Passenger Fishing Vessel Ass'n, 443 U.S. 658 (1979).

"12 For general discussion of the Washington litigation, see Schmidhauser, The Struggle for Cultural Survival: The Fishing Rights of the Treaty Tribes of the Pacific Northwest, 52 Notre Dame Law. 30 (1976); Note, Treaties: Fishing Rights in the Pacific Northwest-The Supreme Court "Legislates" an Equitable Solution, 8 AM. Indin L. REv. 117 (1980); see also Landau, Empty Victories: Indian Treaty Fishing Rights in the Pacific Northwest, 10 ENvTL. L. 413 (1980); Comment, Indian Treaty Analysis and Off-Reservation Fishing Rights: A Case Study, 51 WAst. L. REv. 61 (1975); Note, United States v. Washington (Phase II): The Indian Fishing Conflict Moves Upstream, 12 EnvTL. L. 469 (1982); Note, United States v. Washington: Implied Treaty Rights to Continue Fishing, $18 \mathrm{WL}-$ LAMETTE L. REV. 659 (1982).

113 One of the persons speaking on the Washington experience was George Dysart. In a paper presented several years earlier, Mr. Dysart described the disadvantages of relying on a judicial solution to fisheries management. George Dysart, The Boldt Case and Fishing in the Northwest 15-17 (paper presented to National Council for the Social Studies, 59th Annual Meeting, Portland, Oregon, Nov. 23, 1979).

114 See Arthurs, Master Lands Settlement That Almost Got Away, Legal Times, Apr. 22,1985 , at 1 , col. 2. 
solutions that indicated possible areas of compromise. The court approved the settlement, but one of the tribes overruled its leaders on a subsequent 31-29 vote and decided to proceed with the litigation. ${ }^{115}$ All the other parties ratified the negotiated agreement. The judge severed the two alternative management plans for trial, conducted a trial, and ruled on the merits in favor of the negotiated plan. ${ }^{116}$

Insufficient time has passed to evaluate the success or failure of the negotiated plan. No one appealed the judge's ruling, no subsequent violence has occurred in the lakes, and the policymakers of each of the parties are jointly managing the resource. Most remarkable of all is the agreement's longevity even though one of three tribes rejected it. Given a long history of solidarity among the tribes in this lawsuit, it was almost inconceivable that an alliance among two tribes, the state, and the United States could withstand the pressures of one tribe's dissent.

But significant problems still remain in implementing the agreement. The lines of authority for managing the fish are not clear, there are dislocation problems in certain geographical areas, and the funds provided by the agreement have not been allocated among the tribes. ${ }^{117}$ The parties agreed upon an ADR process, so that the court can resolve any outstanding issues without full trial. ${ }^{118}$ No disputes have yet risen to a level requiring judicial intervention.

1. Economy. The court has requested the special master to evaluate the trial preparation and settlement process, and a report should issue after the next fishing season. Any evaluation will be extremely difficult to accomplish. An economic analysis suggests

${ }_{115}$ United States v. Michigan, File No. M26-73CA (W.D. Mich. Apr. 10, 1985) (Consent Order). In addition to the 31 votes for rejection and 29 votes for acceptance, there were 13 abstentions. Proposed Findings of Fact and Conclusions of Law, submitted by Bay Mills Indian Community, at 9-10, United States v. Michigan, File No. M26-73CA (W.D. Mich. May 14, 1985). On May 4, 1985, a General Council meeting was called to reconsider the rejection; the vote was 139 opposed, 61 in favor, and 4 abstentions. Id.

${ }^{116}$ Pre-Trial Order in Bifurcated Allocation Trial, United States v. Michigan, File No. M26-73CA (W.D. Mich. May 7, 1985).

${ }_{117}$ For example, one tribe expressed concerns over the possible discontinuance of the tribal conservation program and allocation among the tribes of $\$ 180,000$ provided for under paragraph 43(b) of the Agreement for Entry of Consent Order. Letter of Joseph K. Lumsden to Executive Committee of the Sault Ste. Marie Tribe of Chippewa Indians (Sept. 25, 1985) (copy on file with The University of Chicago Law Review).

118 The mechanism is called "U.S. v. Michigan Dispute Resolution Mechanism." It has been described as "a barebones alternetive to the Federal Rules of Civil Procedure." ADR Mechanism Set Up in Great Lakes Fishing Case, Alternatives to the High Cost of LitiGation, Feb. 1986, at 5, 5. 
that the direct expenses were significant-approximately $\$ 200,000$ for master, experts, and expenses. ${ }^{110}$ Attorneys for the parties worked almost full-time on the case from January to March and during May of 1985. Policy leaders and support personnel were also substantially involved during this time. Yet most of these expenses would have been incurred in traditional litigation. The cost to the court in time and money was minimal: only four conferences and a four-day trial. None of the master's rulings was appealed to the court. On balance there was a trade-off between identifiable additional expenses associated with the master's work and unidentifiable savings because of the expedited trial preparation process and the abbreviated trial.

Error and opportunity costs are also difficult to ascertain. All of the parties except for the dissident tribe apparently felt that the outcome minimized their perceived concerns about errors in a court-ordered allocation plan. Given the litigation's twelve-year history and expectations that it would continue indefinitely, settlement was greatly beneficial in that it allowed the parties to devote their energies to other productive endeavors. But the dissenting tribe felt that they failed to achieve their expectations and that their treaty rights had been reduced. ${ }^{120}$ Some concern was expressed that the trial's posture had benefited the majority at the expense of the lone dissenter. As the court's opinion indicates, however, strong support existed for the merits of the negotiated agreement as opposed to the dissenters' management plan. ${ }^{121}$

2. Fairness. The fairness criteria seemed generally satisfied for all except the dissident tribe, but their concerns seemed to relate more to internal leadership policies than to the trial preparation and settlement process. The parties had negotiated the discovery schedule, which was memorialized in a pretrial order. The negotiation dates had been determined far in advance, and all parties seemed well prepared to present their positions. On the other hand, the attorneys' time resources had been spread extremely thin during trial and negotiation. Arguably, the state suffered some disadvantage because of the critical role played by one attorney

119 Expenses were itemized in "Reports of Activities of Special Master" filed with the court periodically during the period from September 28, 1984 through May 14, 1985. The author's compensation and expenses were over $\$ 100,000$, while out-of-pocket expenses and the fees of two independent experts totalled over $\$ 73,000$.

120 See Proposed Findings of Facts and Conclusions of Law and Pretrial Brief of Bay Mills Indian Community, United States v. Michigan, File No. M26-73CA (W.D. Mich. May 14, 1985).

${ }^{212}$ See supra note 115. 
and the short time it had to respond to the final tribal allocation plan. ${ }^{122}$

3. Other Values. The negotiations themselves afforded significant opportunity for maximizing the values of dignity, autonomy, and participation. They took place in Sault Ste. Marie, near the homes of most tribal members; over fifty people were invited to participate. ${ }^{123}$ Media representatives were present for virtually the entire three-day period, although they did not attend the actual negotiations.

Because of the multiplicity of issues that would be contained in any allocation plan and the numerous individuals present in Sault Ste. Marie, negotiations were bifurcated into two separate efforts. Although everyone who desired to participate could do so, the smaller negotiating session was reserved for the named parties, and it coped with the more critical issues.

There was a conscious effort to avoid coercing the parties. The judge attended the opening negotiation session but left soon thereafter. The special master coordinated and facilitated the discussions but never suggested that one outcome was preferable to another. The master's most active intervention was to remind the policy leaders that they had a limited time to determine whether they wanted settlement or trial.

Were the deviations from the traditional trial model-the special master, scorable game, abbreviated discovery schedule, computer-assisted negotiations, and presentation from United States $v$. Washington-justified? Would the parties have settled anyway? Was the settlement "better" than an adjudicated outcome? Given the stated criteria, an ex post analysis suggests that the intervention was worthwhile. Ex ante, however, with the extremely high risk of no settlement, the answers are less clear.

\section{Scientific and Technological Disputes: Will People FREEZE IN THE DarK?}

\section{A. Problem}

During and after the energy crunch of 1973-74 and the high inflation and interest rates in the late 1970s, public utilities repeatedly sought rate relief from the various state utility ratemaking commissions. $^{124}$ In Alabama, a Public Service Commission (PSC)

${ }^{122}$ See Arthurs, supra note 114, at 1, col. 2.

${ }^{123} \mathrm{Id}$.

124 "Rapid inflation had quickly changed a very passive and inactive 'rate of return' 
composed of three individuals elected statewide established utility rates subject to direct appeal to the Alabama Supreme Court. ${ }^{125}$ Hearings before the PSC were noted for widely divergent testimony on scientific, technical, economic, and accounting issues, sprinkled with a high level of emotionalism. Utility ratemaking was probably the most volatile political issue in Alabama during this period. ${ }^{126}$ It was not uncommon for witnesses to testify literally that "people will freeze in the dark" unless rates were reduced. ${ }^{127}$ Utilities countered that industrial development in the state would come to a standstill without money to expand energy generation. The chairman of the Alabama PSC even offered to debate the chief justice of the Alabama Supreme Court on television to resolve the conflict over appropriate utility rate levels. ${ }^{128}$

Since the record on appeal consisted of transcripts of the PSC hearings, the supreme court often received evidence that was extremely difficult to assimilate, both because of its highly technical nature and because of the confusion and disagreement among the experts, even on fundamental premises underlying their testimony. The court's opinions reflected its problems in handling these cases; there was unease in engaging the underlying issues, and critical de-

regulatory process into a very active and continual process of administrative rate of return review." Joskow, Inflation and Environmental Concern: Structural Change in the Process of Public Utility Price Regulation, 17 J.L. \& Econ. 291, 314 (1974) (emphasis deleted).

${ }^{125}$ Ala. Cone $\S 37-1-1$ et seq. (1975 \& Supp. 1985). Prior to 1978, the initial appeal from orders of the Public Service Commission was to the circuit court for Montgomery County, see ALA. CoDE $\$ 37-1-120$ (1975), with further right of appeal to the Supreme Court of Alabama, see AlA. CoDE § 37-1-132 (1975). Since 1978, there has been only a direct appeal to the supreme court. Als. CoDE $\S 37-1-140$ (Supp. 1985). The revision was passed by the legislature with almost no opposition. The change was agreed to by all parties involved in the utility ratemaking process as a time-saving measure since unsuccessful parties at the circuit court level almost always appealed the decision, and the proceedings before the supreme court were in effect de novo because no presumptive weight was given the trial court's ruling. See Osborne Truck Lines v. Alabama Pub. Serv. Comm'n, 284 Ala. 166, 168, 223 So. 2d 284, 286 (1969).

${ }^{126}$ In a study of utility regulatory bodies, the Alabama PSC was characterized "as a panel whose decision are based on members' political ambitions, rather than on facts." Kovacs \& Bailey, Investors Give PSC Low Marks, Birmingham News, Jan. 25, 1982, at 1A, col. 1. Commissioners convey to the public images of "white knights fighting the rich utilities and moneyed, out-of-state investors who own their stock." Id.

122 The Attorney General intervened as a representative of the consumers and argued that utility rates were too high. At one point, several low- and fixed-income individuals, represented by Legal Services attorneys, intervened and testified at the PSC hearings that they were having to choose between eating and paying their power bill.

${ }^{128}$ Before a civic group, Billy Joe Camp, then president of the PSC, stated: "I'll defend these (PSC decisions) anywhere, anytime with anybody, with either one member of the [supreme] court or all nine, with one person from the power company or with them all." Taylor, Let PSC set utility rates or abolish it, Camp says, Birmingham News, Oct. 21, 1981, at 2A, col. 1 . 
cisions often turned on conclusory normative statements, creative fictions, or procedural niceties such as standards of review or burdens of proof. ${ }^{129}$ Concern was expressed that some justices were inclined to go outside the record to find scientific support for their opinions. ${ }^{130}$

Members of the supreme court were concerned about the perceived legitimacy of their decisions in these cases because they lacked confidence in their ability to address the merits of these complex technical disputes. ${ }^{131}$ The frequency and intensity of appeals and the public statements by the interested utility ratemaking constituency confirmed that the court was having difficulty in providing rational predictability in its decisionmaking processes.

\section{B. Diagnosis}

An initial diagnosis of these disputes suggested that both institutional and strategic components underlay the court's problems. The parties were apparently convinced that the outcome of PSC hearings would be governed by political concerns rather than by the economic or accounting aspects of utility ratemaking. The evidence they presented before the PSC tended to reflect political posturing supported by tenuous expert testimony. The parties also believed that each case would be appealed to the supreme court, and that the court would decide the constitutional issue of confiscation by independently reviewing the evidence presented to the PSC. Yet the parties had little confidence that the court could handle the economic and accounting issues. Rather, they expected the court to fail to sort out difficult scientific and technical issues and to render its decisions on other grounds.

The parties' strategy was to emphasize the arguments on basic

129 For example, when Alabama Power Company sought a direct appeal to the Supreme Court of Alabama of a PSC ruling on the treatment of advertising cost as a rate base item, the court avoided the substantive issue on jurisdictional grounds. APC loses bid in court, but won't give up fight, Birmingham News, May 10, 1981, at 29A, col. 1 .

130 This concern surfaces in many contexts. See, e.g., United States v. 1,078.27 Acres of Land, 446 F.2d 1030, 1034 (5th Cir. 1971) ("A major risk when the trial judge resorts to outside sources to verify facts is that he may choose to decide the whole dispute on the basis of his own independent research."), cert. denied sub nom. Galveston City Co. v. United States, 405 U.S. 936 (1972).

${ }_{131}$ "The lack of a sound factual base in promulgating general norms raises the question of legitimacy." Miller \& Barron, The Supreme Court, the Adversary System, and the Flow of Information to the Justices: A Preliminary Inquiry, 61 V. L. REv. 1187, 1228 (1975). See generally Phitip B. Kurland, Politics, the Constitution, and the Warren Court 170-206, 196 (1970) ("The Court, because it is a court, lacks machinery for gathering the wide range of facts and opinions that should inform the judgment of a prime policy-maker."). 
value judgments and to present economic and accounting evidence only insofar as it supported the political positions. This polarized the scientific and technical expertise, so that the record contained economic and accounting testimony at the extremes of the distribution of scientifically acceptable evidence. Thus, the parties rarely joined issue on the economic and accounting evidence, and the court never heard information from the center of the evidentiary spectrum. The adversarial process had so polarized the parties' positions that the court was almost forced to choose between unacceptable alternatives; it was final offer arbitration run amok..$^{132}$

Compromise was not a feasible alternative. The PSC, the various consumer groups, and their supporting politicians had invested so much political capital in their positions that any wavering would appear to be defeat. Utilities generally felt compelled to stake out a correspondingly strident position in order to protect their future customers and shareholders. The parties' public positions suggested that they would prefer presenting and arguing their cases more on the merits but felt trapped in their current strategy. ${ }^{193}$ Therefore, the task in developing an alternative procedure would be to create incentives for the parties to present clear and comprehensive testimony in the center of the acceptable evidentiary spectrum and then join issue on that evidence, without removing the proceedings from the adversarial process or diluting the role of the supreme court.

When the Alabama legislature passed the statute providing for direct appeal from the PSC to the supreme court, the chief justice added a provision allowing the court to hire an expert to assist its decisionmaking. ${ }^{134}$ The chief justice then requested a law professor to develop an appellate procedure for the court to employ experts.

132 See supra note 105. This form of arbitration is currently being used in professional baseball to resolve salary disputes. See Grebey, Another Look at Baseball's Salary Arbitration, 38 ARB. J., Dec. 1983, at 24; Miller, Arbitration of Baseball Salaries: Impartial Adjudication in Place of Management Fiat, 38 ARBitration J., Dec. 1983, at 31.

13s For example, while Attorney General Charles Graddick employed experts to review Alabama Power Company's rate requests and to testify at PSC proceedings, he was still compelled to make public statements attacking the utility and its behavior. Holmes, Opponents will line up to halt rate hike request, Birmingham News, March 22, 1981, at 11A, col. 2 ("Historically, Alabama Power Co. makes rate requests that are far greater than they need.").

134 See ALA. CoDE § 37-1-143 (Supp. 1985). 


\section{Prescription}

The addition of an inquisitorial element in the form of an expert seemed appropriate to accomplish these tasks. It would be necessary, however, to devise a procedure that would be acceptable to the parties and their attorneys while providing sufficient guidance to the court. After extensive meetings with virtually all interested persons, the professor drafted rule 33A of the Alabama Rules of Appellate Procedure to govern the use of an appellate expert in utility ratemaking cases. ${ }^{135}$ The theory behind rule $33 \mathrm{~A}$ was that the expert's mere presence would alter the parties' strategies and encourage them to present more digestible information to the court. If the court could recognize when evidence was drawn from the tails of a distribution of acceptable economic and accounting information, it could discount that evidence accordingly. Realizing this, the parties should present more generally accepted testimony in a clear and comprehensive fashion. The chances would correspondingly increase that parties would actually join issue on disputed matters. Then the court could more easily engage these issues in a reasoned fashion. If the theory were correct, the court might not even need to appoint an appellate expert; the mere threat would suffice to accomplish this goal.

1. Parties. The rule 33A endeavor added two new players: a creator of the process and an appellate expert on economic and accounting issues. Drafting the new procedural rule was accomplished over a six-month period and involved participation by virtually every party or attorney who expressed an interest in utility ratemaking proceedings. It culminated in a vote of approval by the Advisory Committee on the Alabama Rules of Appellate Procedure. ${ }^{136}$

The rule provides that an appellate expert in each case is selected from a list provided by the parties and the court. ${ }^{137}$ First the court narrows the list of candidates to three; then the appellants and appellees each have one strike; the remaining person is the appellate expert for that case. In the initial version of the rule, no oral communication was permitted between the expert and the court or the expert and the parties. ${ }^{188}$ The expert would respond in

138 Ala. R. ApP. P. 33A.

138 The rule was drafted by the Alabama Appellate Rules Committee with the assistance of the author and became effective on March 6, 1981, after approval by the Alabama Supreme Court. Id. 33A.

197 Id. $33 \mathrm{~A}(\mathrm{~b})(1)$. If the parties agree on a particular expert he will be appointed. Id.

${ }^{158}$ Id. $33 \mathrm{~A}(\mathrm{~b})(2) \&(\mathrm{c})(3)$. 
writing to inquiries addressed by the court and made available to the parties. ${ }^{139}$ The parties would also receive the expert's responses, so that they might object or raise additional issues. ${ }^{140}$ The appellate expert would not report conclusions on any ultimate issues, but would assist the court in coping with the evidence contained in the record on appeal. ${ }^{141}$

By sharply limiting the expert's function, forbidding ex parte communication, and including strict ethical standards, there was a consensus that most of the traditional objections to court-appointed experts had been overcome. ${ }^{142}$ The selection process and method of communication were also designed to foster the use of experts who had previously refrained from testifying in an adversarial proceeding out of a distaste for cross-examination.

2. Issues. Since the expert could not go outside the appellate record or decide ultimate issues, there was little potential for issue expansion. The rule's goal was just the opposite-to narrow the issues. Just as a law clerk takes the record and a mass of briefs and organizes a bench memorandum, the expert could organize and summarize the economic and accounting evidence. The court could, for example, list the legal issues in the case and request the appellate expert to organize the evidence that each side had presented on each issue. The expert's response might include the critical economic or accounting subissues under each legal issue indicating where joinder had or had not occurred.

The importance of issue definition by the appellate expert should not be underestimated, however. Recent work in agenda theory illustrates that issue framing and issue sequencing can be critical. ${ }^{143}$ Often the major dispute in a case is over the issues to be decided, either at the factual or legal level..44 With this in mind, multiple safeguards were designed into the rule to constrain the

1s? Id. $33 \mathrm{~A}(\mathrm{c})$.

${ }_{110} I d .33 \mathrm{~A}(\mathrm{~d})$.

${ }_{161} I d .33 \mathrm{~A}(\mathrm{c})(5)$.

143 See, e.g., FED. R. Evid. 706 Advisory Comm. notes; Botter, The Court-Appointed Impartial Expert, in Using Experts IN CrvIL CASEs 53 (M. Kraft 2d ed. 1982); see also Sheppard, Court Witnesses-A Desirable or Undesirable Encroachment on the Adversary System?, 56 AuSTRL. L.J. 234 (1982). On the particular dangers posed by ex parte communications, see Brazil, Special Masters in Complex Cases: Extending the Judiciary or Reshaping Adjudication?, 53 U. CHI. L. Rev. 394, 421-22 (1986).

${ }_{143}$ See Levine \& Plott, Agenda Influence and Its Implications, 63 VA. L. REv. 561 (1977); Plott \& Levine, A Model of Agenda Influence on Committee Decisions, 68 AM. Econ. REv. 146 (1978).

244 See P. Gulliver, supra note 40, at 126-27. 
expert's power in this task..$^{145}$

3. Information. As with the issues, the appellate expert would not supplement existing testimony but would merely identify economic and accounting information and enable the court to distinguish gradations in the applicability and quality of evidence. If the parties failed to present relevant information comprehensively, however, the appellate expert could advise the court that evidence outside the record would be necessary in order to respond to an inquiry. The court could then request the parties to present additional testimony.

Probably the appellate expert's most important function would be to communicate information in a form assimilable by members of the court. ${ }^{146}$ Multiple applications of psychological tests to a wide variety of professionals suggests a high correlation between cognitive style and occupation. ${ }^{147}$ Some studies suggest that major differences exist between the cognitive styles of judges and experts, which can preclude effective communication. ${ }^{148}$ Judges, for example, tend to view problems as zero-sum games and seek "right" or "wrong" answers. ${ }^{149}$ Some scientists, on the other hand, concentrate more on underlying concepts and gradations in correctness. ${ }^{180}$ The phenomena of judges seeking particular blackand-white answers from economists based upon a single snapshot frozen in time and experts dreaming of judges who deal with general concepts in terms of probability distributions appear to be almost universal.

In addition to cognitive style, the rule also stressed the method of communication. It was originally assumed that the inquiry-response format-borrowed from interrogatory methodology-would provide high-quality information. ${ }^{151}$ Subsequent analy-

${ }^{145}$ See supra notes $138-41$ and accompanying text.

${ }_{148}$ ALA. R. App. P. 33A(b)(3)(C).

${ }^{147}$ See Kerin \& Slocum, Decision-Making Style and Acquisition of Information: Further Exploration of the Myers-Briggs Type Indicator, 49 Psychological Rep. 132 (Aug. 1981).

${ }_{148}$ See Curlin, Law, Science, and Public Policy: A Problem in Communication, in Scientists in the Legal System 35, 36 (W. Thomas ed. 1974).

${ }^{149}$ "The overall hypothesis presented here is that the rule-based, fact-dominated process of legal reasoning attracts individuals whose cognitive style has difficuity with and often rejects the legitimacy of the scientists' mode of thinking, which emphasizes uncertainty, complexity and conceptual issues." Keen, Cognitive Style and Lawyers and Scientists 11 (Mar. 1981) (paper presented at Conference on Resolving Regulatory Issues Involving Science and Technology, April 9-11, 1981, conducted by National Center for Administrative Justice).

${ }^{180} I d$.

${ }^{261}$ See FED. R. Crv. P. 33 (advisory committee notes focus on insuring clarity and accu- 
sis suggested that the format prevented sufficient timely feedback. In using rule $33 \mathrm{~A}$, therefore, the court employed a rule 33 prehearing conference wherein three justices, the appellate expert, the parties, and their attorneys conducted a series of oral inquiries and responses using the same format as the written ones. ${ }^{122}$ The final version of rule $33 \mathrm{~A}$ recommended that the initial communications between the court and expert be in writing, followed by an opportunity for oral inquiries and responses in a conference either before or after oral argument.

\section{Results}

An ongoing evaluation of five rule $33 \mathrm{~A}$ interventions suggests that the process has some merit. ${ }^{153}$ A quasi-experimental design attempts to measure, both qualitatively and quantitatively, the rule's overall benefits and losses as compared to the traditional appellate procedure. ${ }^{154}$ The briefs, oral arguments, expert responses, and opinions from utility ratemaking cases before, during, and after the intervention were selected and examined with research protocols to measure numbers of issues raised, the longevity of those issues, frequency of joinder of issues by the parties, and engagement by the supreme court. Utility ratemaking experts performed more subjective analyses of this same material to measure the clarity and comprehensiveness of the economic and accounting evidence and discussions. Interviews of relevant interested individuals, including members of the Alabama Supreme Court and the actual appellate experts, were conducted before, during, and after the intervention using survey instruments and open-ended discussions.

1. Economy. The number of utility ratemaking appeals decreased sharply after appellate experts began to be employed. ${ }^{155}$

racy of the information); Haydock \& Herr, Interrogatories: Questions and Answers, 1 Rev. of LiTIG. 263, 265 (1981) ("Interrogatories reveal] information which will put the parties in realistic and informed positions from which to negotiate a settlement or stipulate to agreed facts.")

${ }^{163}$ ALA. R. APr. P. 33. The prehearing conference was utilized in Union Springs Tel. Co. v. Alabama Pub. Serv. Comm'n, 437 So. 2d 485, 487 (Ala. 1983).

16s The author is currently completing a study of the appellate expert experiment with Professors John Heilman of Auburn and Dan Nyhart of MIT.

154 For descriptions of quasi-experimental design techniques, see Carol Weiss, Evalu-

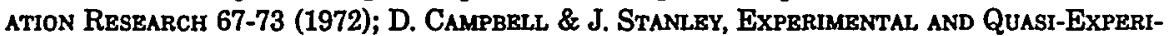
MENTAL Designs for RESEARCh 34-64 (1963). For an application of evaluation research in a legal context, see Kelly, Social Science Evaluation and Criminal Justice Policy-Making: The Case of Pre-Trial Release, in Public Policy Evaluation 253 (K. Dolbeare ed. 1975).

${ }^{165}$ From 1976 to 1980, there were seven appeals; from 1981 to 1983, there were seven; from 1984 to 1986, there were three. 
Arguably this occurred because the parties needed rational and predictable answers from the court to a relatively small number of issues in order to evaluate their cases accurately. Once those issues had been decided, the parties were able to compromise, because their extreme positions had been eliminated. Anecdotal evidence involving Alabama's largest and most politically sensitive utility suggests that this is precisely what happened - much to the satisfaction and relief of all parties interviewed. On the other hand, a number of complicating factors, such as the decline in the inflation rate and changes in the state's political climate, weaken the suggestion that rule $33 \mathrm{~A}$ was a major cause of the reduction in appeals. Current techniques cannot evaluate the relative importance of these and other variables.

However, virtually all of those interviewed consider the rule a worthwhile experiment. ${ }^{158}$ The quantitative and qualitative evaluations also suggest that the intervention correlated with a reduction in issues requiring court decision, clearer and more comprehensive economic and accounting evidence, increased joinder of issues by the parties, and more substantial engagement by the court of the fundamental questions raised on appeal.

Using the previously stated economy criteria, both ex ante and ex post analyses indicate that the intervention was worthwhile. The biggest problems were related to cost and time. The appellate experts' fees totalled approximately $\$ 30,000$. There were six instances of inquiries-responses and one prehearing conference. The parties' additional costs are not available but must be a substantial multiple of the appellate experts' fees.

Justices of the court were generally dissatisfied with the inquiry-response communication format. They doubted whether the appellate expert understood their questions. Moreover, they found the time lag between posing inquiries and receiving responses unacceptable, because it forced them to refamiliarize themselves with the case repeatedly. The prehearing conference ameliorated this situation somewhat, although the justices would have preferred a conference without previous written communication.

Still, the savings in error costs may substantially outweigh these direct expenses. If the reduced number of appeals is at all attributable to the rule, there would be enormous savings to the court, the parties, and particularly to Alabama citizens and utility company shareholders. If stock prices and bond ratings, net of

${ }^{158}$ Interviews of various participants in the utility ratemaking process were conducted by Professor John Heilman and the author. 
market effects, are any surrogate for error costs, the savings far outweigh the expenses associated with the implementation of the rule. ${ }^{157}$ In addition, if the initial development costs of the rule are viewed as a capital expense, the amortization of that expenditure over the life of the rule would mitigate its negative impact.

Because of the extreme amount of energy devoted to designing and implementing the rule, a "Hawthorne effect" may explain some of its perceived success. ${ }^{188}$ Since the court and parties knew that they were subject to intense scrutiny by academic evaluators, they may have worked harder to produce a favorable outcome. If this were true, the opportunity costs may have been significant. However, in the Hawthorne experiment, the workers had little to gain by working harder; in contrast, the ratemaking cases had independent significance for both court and parties. Therefore, any synergy here from the presence of observers must be severely discounted.

2. Fairness. Concerns of predictability and rationality seemed to be met and even exceeded; virtually all the interviews support that conclusion. Equality of opportunity and strategy were particularly strong as well. Each side applauded the use of the appellate expert on the theory that the court could finally understand their evidence and find it persuasive. After opinions were rendered and even in the presence of substantial disagreement with the outcomes, most observers believed that the court was able to appreciate the testimony presented to it.

Probably the most interesting aspect of the experiment-the

${ }^{237}$ The utilities' major criticism of the ratemaking cases before rule 33A was the detrimental impact the PSC's actions were having on their ability to raise funds by selling longterm bonds and capital stock. For example, from 1978 to 1981, Alabama Power Company's long-term bond rating was "Baa" and its capital stock rating was "ba" in Moody's Public Utility Manuals. In 1981 its ratings began improving, and by 1985 the ratings were "A1" and "a2" respectively. Such improvements arguably allow the utility to raise funds more easily and cheaply.

iss The Hawthorne effect refers to a series of studies conducted at Western Electric's Hawthorne Plant in Chicago, which manufactured telephone equipment, between 1924 and 1932. In three experiments on the impact of changes in the amount of lighting on production rates, the level of production always increased regardless of what change was made to the illumination. See Parsons, What Happened at Hawthorne?, 183 Scrence 922, 922 (1974). The popular belief was that the subjects endeavored to give the researchers the perceived desired outcome. The validity of this view has been questioned. See id.; see also Adair, The Hawthorne Effect: A Reconsideration of the Methodological Artifact, 69 J. APPLIED PsYchOLOGY 334 (1984). For additional analyses of the problems of the overly cooperative subject, see Adair \& Schachter, To Cooperate or to Look Good?: The Subjects' and Experimenters' Perceptions of Each Others' Intentions, 8 J. ExPERIMENTaL Soc. PsychoLOGY 74 (1972); Sigall, Aronson \& Van Hoose, The Cooperative Subject: Myth or Reality?, 6 J. Experimental Soc. Psychology 1 (1970). 
use of an expert by an appellate court-never generated significant debate. Because of the direct appeal, the court's de novo review of the confiscation issue, and perceived dissatisfaction with the existing system, none of the interested parties seemed concerned with this unprecedented use of an expert. If rule $33 \mathrm{~A}$ were used in other contexts, however, intense debate would probably ensue. ${ }^{158}$

3. Other Values. Values of dignity and participation were also apparently satisfied. The parties seemed reassured that by participating in selecting the expert and having an opportunity for a prehearing conference, their positions were effectively presented and were understood by the court.

Although it appears that the intervention was worthwhile, the court has not sought permanent funding for appellate experts nor has it expanded rule $33 \mathrm{~A}$ beyond utility ratemaking. Courts in other states may be interested in adopting the rule, but no implementation has yet occurred outside of Alabama. The delay in publishing an evaluation and limited dissemination of information concerning rule 33A may partially account for the absence of transfer at this time.

\section{Mass Torts: Can We Prioritize the Queue?}

\section{A. Problem}

Approximately 9,000 asbestos-related personal injury cases were filed nationally between March 1983, and July $1985 .{ }^{160}$ Many commentators suggest that they pose a significant threat to the viability of our litigation system, in that the courts cannot render rational decisions in these cases at an acceptable cost in time and money. ${ }^{161}$

In the initial stages of the asbestos litigation difficult legal issues were presented to the courts: the "state of the art" defense, scope of insurance coverage, statutes of limitations, identification of parties, and evidentiary questions such as the admissibility of

${ }^{160}$ Relatively few attorneys represent parties in utility ratemaking procedures. The Advisory Committee on the Appellate Rules of Procedure and the bar generally deferred to the desires of these few attorneys. In other types of litigation, there would be greater difference of opinions and less likelihood of consensus.

${ }^{160}$ D. Hensler, W. Felstiner, M. Selunn \& P. Ebener, Asbestos in the Courts: The Challenge of Mass Toxic Torts 21 (1985) (33,000 asbestos actions as of July 1985, up from 24,000 in March 1983).

${ }^{261}$ See, e.g., Smith \& Channon, The Rising Storm, 17 Forum 139 (1981). 
evidence of design changes. ${ }^{162}$ Although a few legal issues remain to be resolved, most jurisdictions have set legal standards on most issues. ${ }^{163}$ Historically, the factual issues have not been unusually complex; testimony concerning liability, exposure, and injuries is similar to what one would expect in other product liability tort cases. ${ }^{184}$ The real complexity comes from the huge number of plaintiffs and defendants. On average, each plaintiff sues twenty defendants, and judges frequently find more than fifty lawyers at pretrial conferences. ${ }^{168}$

In some jurisdictions the resolution of asbestos disease cases correlates with normal disposition rates. ${ }^{166}$ In other jurisdictions there is substantial stagnation. ${ }^{187}$ The variance can largely be explained by the rate and number of filings, the number of competing cases, the attention given by the judiciary, the behavioral patterns of the local bar, and the incentives of parties and attorneys. In jurisdictions where dockets have become overloaded, the resources of courts, attorneys, and parties are simply inadequate to cope. Typically an extremely small number of firms represents massive numbers of plaintiffs; it would not be unusual for a single lawyer with four associates to represent over a thousand clients. ${ }^{168}$ Defense teams are typically of similar size. ${ }^{169}$ The defendants' resources-in both defending suits and paying judgments-are often strained. These problems become particularly acute in the absence of cooperation among the lawyers. After August of 1982 the absence of the Manville attorneys, who had been the natural leaders of the defense effort, sometimes left an organizational vacuum

162 See K. Bushnell \& W. Jordan, Recent Developments in Asbestos litigation (1984); see also McGovern, Toxic Substances Litigation in the Fourth Circuit, 16 U. RICH. L. REv. 247 (1982); Comment, An Examination of Recurring Issues in Asbestos Litigation, 46 ALB. L. REv. 1307 (1982).

103 Thomas E. Whlging, Asbestos Case Management: Pretrial and Trial ProceDURES 9 (1985). 1985).

${ }^{104}$ See, e.g., Wilson v. Johns-Manville Sales Corp., 107 F.R.D. 250, 253 (S.D. Tex.

${ }_{168}$ Parrish, Dimensions of the Problem, 8 STATE CT. J. 5, 6-7 (1984); see also Hamilton, Rabinovitz \& Szanton, Inc., Cutting the Overhead Costs of Resolving Asbestos Claims: $A$ Time for Action, 6 J. Prod. LiaB. 17, 22 (1983).

${ }^{106}$ See D. Hensler, W. Felstiner, M. Selvin \& P. EBener, supra note 160, at 84-85.

187 See id. (among the results found by the Rand Corporation's researchers were: after more than six years of litigation, only $11 \%$ of cases filed in state court in San Francisco had been completed; the disposition rate of action cases in the Middlesex, New Jersey, state court was less than $20 \%$; and at a present [annual disposition] rate of $13 \%$, it will take decades to resolve the claims filed in the Philadelphia Court of Common Pleas).

${ }^{188}$ Id. at 89 n.6.

169 J. Kakalik, P. Ebengr, W. Felstiner, G. Haggstrom \& M. Shanley, Variation in Asbestos Litigation Compensation and Expenses 20 (1984). 
which has exacerbated this situation. ${ }^{170}$

Regardless of the local situation, approximately 98 percent of the asbestos disease cases that were resolved were settled; only 2 percent of the cases concluded with a jury verdict. ${ }^{171}$ Most settlements, however, occurred on the eve of trial. The major bottleneck was the scarcity of trial dates; judicial trial time became the scarcest resource in the dispute resolution process.

In 1983 there were almost 80 asbestos cases pending in the Northern District of Ohio. Some of them had been on file for over three years and had been assigned to nine different judges. Two trials had been held in federal court, one in state court, and 64 cases had been settled. Judge Thomas D. Lambros decided that the resolution rate of the asbestos disease cases had been sufficiently desultory and was so delaying the progress of unrelated cases that a new methodology was needed to handle them. ${ }^{172} \mathrm{He}$ consolidated all the asbestos cases in his court and appointed two special masters to develop an Ohio Asbestos Litigation Case Management Plan (OAL Plan) for resolving all pending cases within a two-year period. ${ }^{173}$

\section{B. Diagnosis}

The high settlement rates in asbestos disease cases can be explained in part by the medical consensus that asbestos does cause certain diseases-asbestosis, mesothelioma, and certain other cancers. ${ }^{174}$ The genuine issues in these lawsuits typically concern whether this plaintiff was exposed to asbestos, whether the asbestos was manufactured by these defendants, whether it was manufactured at a time when defendants did not fulfill their legal obligations to users of their products, and whether this plaintiff's injuries were asbestos-related. For individuals who had a disease caused by asbestos and who had experienced massive exposure to

${ }^{170}$ Johns Manville Corporation, one of the foremost producers of asbestos products in the United States, filed for reorganization under Chapter 11 out of a concern that its assets were insufficient to satisfy all potential claims for personal injury and property damage from asbestos. See, e.g., In re Johns Manville Corp., No. 82 B 11656 (BRL) (Bankr. S.D.N.Y., pending since 1982).

271 Ohio Asbestos litigation: Case Management Plan and Case Evaluation and Apportionment Process 5-6 (Dec. 16, 1983).

${ }^{272}$ In re Ohio Asbestos Litigation, No. 83-OAL (N.D. Ohio General Order No. 67 filed June 1, 1983).

${ }_{173} I d$. (N.D. Ohio Order No. 3 filed July 14, 1983).

174 See I. Selikoff \& D. LeE, Asbestos AND Disease 143-56, 241-44, 262-66, 307-21, 326 27 (1978); Becklake, Asbestos-related Diseases of the Lungs and Pleura, 126 AM. REv. RESPIRATORY DisEASE 187 (1982). 
asbestos when the producers had a legal duty to reduce the risk of exposure to asbestos but did not, the only argument was over the amount of money that should be paid.

Ironically, the success of the obviously-injured plaintiffs created much of the asbestos litigation problem. Virtually anyone who had ever worked with asbestos had an incentive to bring suit. The commons became standing room only. ${ }^{178}$ Our traditional litigation mechanism, which values minimizing false-positive damage awards-awarding no compensation to undeserving plaintiffs-mandated first-come, first-served individual trials. As a result, a lengthy queue of litigants developed. Defendants and even some plaintiffs' attorneys had little incentive to expedite the decisionmaking process-the plaintiffs themselves bore the brunt of the slowdown. ${ }^{176}$

Because of the extensive history of asbestos litigation, however, there was some theoretical support for an ADR methodology to prioritize the cases in the queue that Judge Lambros regarded as unacceptably long. ${ }^{177}$ If some mechanism could identify the probable true positive and true negative plaintiffs early and inexpensively, then plaintiffs who had greater chances of succeeding might be placed at the head of the queue. Defendants appeared willing to settle in clear cases, but desired more scrutiny for the less obviously meritorious suits. If greater judicial resources were allocated to the more serious cases, they should settle quickly; then public acceptance should develop for the remaining cases to compete with other lawsuits for judicial attention. This was precisely what the Speedy Trial Act did by expediting the resolution of criminal cases. ${ }^{178}$

This theory views litigation as an information system generating massive amounts of data, from which one can isolate the variables critical to jury awards and settlements. ${ }^{179}$ It then might be

175 Just as the village or global commons may be destroyed by overuse, see supra note 98, the assets of defendants may be totally depleted before all claims are satisfied. In filing for Chapter 11 reorganization, the Johns Manville Corporation cited "a predicted \$2 billion liability to unknown, future claimants." Riley, Asbestos: New Approaches, Nat'l L.J., May 7, 1984, at 1, col. 1 \& 25, col. 1; see also Lauter, Dalkon Shield Cases Thrown into Disarray, Nat'l L.J., Mar. 17, 1986, at 1, col. 2 \& 10, col. 1 (by mid-1985, A.H. Robins and its insurer had expended nearly $\$ 517$ million in judgments and settlements).

${ }^{176}$ See D. Hensler, W. Felstingr, M. SkLvin \& P. Ebenkr, supra note 160, at 89-94.

177 See In re Ohio Asbestos Litigation, No. 83-OAL (N.D. Ohio Order No. 2 filed June 15, 1983 \& Order No. 3 filed July 14, 1983).

${ }^{278}$ See 18 U.S.C. \& 3161 (1982).

170 See generally Francis E. McGovern, Resolving Mature Mass Torts (1986) (unpublished manuscript). 
possible to list the outcome-determinative factors, weigh their relative importance, and create a model to predict the value of pending cases. Prioritizing can then be performed on a reasoned basis.

The arguably idiosyncratic nature of litigation outcomes might limit the predictive power of the information generated. In the mass tort context, however, it has been suggested that a marketplace of multiple trials, over time, results in a rough equilibrium of case values. ${ }^{180}$ This cyclical theory of mass torts holds that a defined pattern in these cases will culminate in trials and settlements having approximately equivalent outcomes. In the early stages of the cycle, defendants tend to win more cases than plaintiffs because of strategic and informational superiority. If the litigation has any merit, however, plaintiffs will eventually develop successful information and strategies and win an extremely high percentage of the cases tried. Next, the plaintiffs will bring cases for trial that stretch the envelope of viable plaintiffs too far, and defendants will create more effective counterstrategies, resulting in a reduced percentage of plaintiff victories. Eventually, after full aggregation and dissemination of information, crystallization of the law, and thorough development of strategies, there will be a rough equilibrium of trial results. Remaining variations will then be due to jury demographics, attorney caliber, and random events during trials. ${ }^{181}$ Although perhaps it is counter-intuitive, settlements will also reflect this equilibrium: the average settlement amount will be virtually identical to the average jury verdict. ${ }^{182}$ The variance, however, will be substantially different. ${ }^{183}$ Settlements for similarly situated plaintiffs will be extremely similar; verdicts will vary in accordance with idiosyncrasies of the trial process.

If this cyclical theory of mass torts were remotely correct, it would be feasible to extrapolate from the information generated in the equilibrium state to predict the values of pending cases. If the parties could use these predictions to evaluate their cases prior to expending the substantial transaction costs associated with discovery and trial, both sides would have an incentive to settle. Under classic negotiation theory, most personal injury suits are viewed as

180 Id.

181 See Priest \& Klein, The Selection of Disputes for Litigation, 13 J. LEGaL STUd. 1, 3-6 (1984).

182 See, e.g., 1 John E. Rolph, Automobine Accident Compensation, Volume 1: Who Pays How Much How Soon? 26-27 (1985) (results of a study of the experience in automobile accidents).

${ }^{183}$ Id.; cf. H. RAIFFA, supra note 76, at 70-73. 
zero-sum games or distributive bargains. ${ }^{184}$ Each additional dollar received by a plaintiff comes directly from a defendant's pocket. In contrast, furnishing both sides with case value predictions should permit them to bargain integratively. ${ }^{185}$ When the difference between defendant's offer and plaintiff's demand is less than the projected transaction costs for traditional trial, each side would benefit by settling anywhere between that offer and demand.

The key problem with this scenario relates to the fundamental goal of expediting payments to plaintiffs through private settlements. Defendants, eager to retain their limited resources by slowing the velocity of cash outflow, might still resist early settlements, particularly if they perceived that several jurisdictions would adopt similar procedures. Plaintiffs' attorneys might prefer traditional procedures because they tend to satisfice ${ }^{188}$ under the traditional system and would find the lack of public knowledge of jury verdicts detrimental to their efforts to seek recompense for as yet unidentified plaintiffs. Other incentives, such as limiting fees for plaintiffs' attorneys and structuring settlements over time, might be necessary to encourage defendants further. Given the small number of plaintiffs' attorneys and a recognition that their contingent fees involved little contingency, mass settlements might still be palatable even with these limitations. The fundamental problem here was to determine how far the court could and should go in creating artificial incentives that arguably would rob a party of its rights to due process by effectively coercing settlements.

\section{Prescription}

In accordance with the appointment by Judge Lambros, the special masters designed a case management plan that alters the traditional procedural model by adding both cooperative and in-

184 "Distributive bargaining is concerned with the allocation of shares within the framework of a relatively fixed set of resources." Erickson, Holmes, Frey, Walker \& Thibaut, Functions of a Third Party in the Resolution of Conflict: The Role of a Judge in Pretrial Conference, 30 J. Personality \& Soc. Psychology 293, 294 (1974). Any gain by one party requires a corresponding loss by the other party. A dispute over money, such as a personal injury lawsuit, generally involves distributive bargaining.

${ }^{185}$ For example, among the cited virtues of the mini-trial are that it allows a "greater capacity to arrive at 'win/win' results (negotiation) because the business representatives can work out their integrative solution," S. GoldBerg, E. GREEN \& F. SANDER, Dispute REsoluTION 274-75 (1985), and that it potentially saves the cost of continuing litigative combat, id. at 277-78.

186 This term was coined by economist Herbert Simons to describe a decisionmaker who is willing to "settle for good-enough answers in despair of finding best answers." Simons, Administrative Decision Making, 25 PuB. AD. Rev. 31, 33 (1985). 
quisitorial components. ${ }^{187}$ Not all parties had complete data concerning past trials and settlements. Typically, a plaintiff achieved settlement by negotiating with individual defendants, who seemed less concerned with how much they paid in absolute dollars than with how much they paid relative to other defendants. As a result, some defendants preferred to keep their settlement amounts secret. Plaintiffs, not reluctant to play defendants off against each other, were the only ones to know the total settlement value of most cases. The masters arranged to gather that information and compile it in a form that each party could use.

The parties were interviewed in great detail concerning the objective and subjective factors by which they evaluated cases. Then discovery was scheduled so that the minimum information essential for an acceptable case evaluation would be gathered first. Next, a pretrial conference allowed the parties to explore settlement possibilities prior to expending substantial funds to obtain data that would be more valuable for trial. To assist this process, we examined the kinds of evidence typically gathered for various purposes, and attempted to ensure that the marginal cost of obtaining information for settlement did not exceed its marginal value. One by-product of applying this theory was to defer the most expensive discovery until after the initial settlement conference, thereby increasing the chances for integrative bargaining. Finally, the masters felt that communication breakdowns among the parties warranted the use of mediation. We recommended that Judge Lambros, who has a national reputation as an effective settlement facilitator, fulfill that role.

This prescription relied upon procedures that were generally acceptable to the parties as long as they felt they had the ultimate option of seeking a jury determination. We deferred recommending more draconian proposals that would intensify the pressures for settlement. The OAL Plan did, however, list a number of alterations that might be considered if the process did not function satisfactorily. ${ }^{188}$ Despite the mildness and acceptability of its innovations, the OAL Plan was criticized for valuing expedition over accuracy.

1. Parties. Given the large number of plaintiffs and the lim-

187 Ohio Asbestos Litigation: Case Management Plan and Case Evaluation and ApPORTIONMENT Process 11-12.

${ }_{188}$ Id. at 105-12 (the suggestions included abbreviated Consolidated Discovery Requests, counsel coordination, offers of settlement, pre-judgment interest, discovery restrictions, and standardization). 
ited time Judge Lambros had allocated, it was necessary to consolidate cases for disposition. The cases were organized into separate clusters of five cases each. ${ }^{189}$ The key issue was how to constitute each cluster. Should we select cases by the traditional first-come, first-served method, or group similar cases to facilitate presenting evidence at trial, or combine cases representing each of the plaintiff categories? Differences-oriented negotiation theory suggested that settlements would be easier to achieve by creating bargaining groups including both weaker and stronger cases from each side's perspective. We decided, therefore, to select a representative case from each disease category. To streamline the process further, the clusters were organized into two separate tracks that would proceed concurrently through the litigation schedule. Thus, ten cases would be available for treatment at each stage of discovery, settlement negotiation, and trial.

While increasing the number of plaintiffs, the OAL Plan suggested reducing the number of defense counsel as much as possible. Since the local bar had de facto leaders, it was not necessary to appoint lead counsel. The negotiations among producers of asbestos and their insurers subsequently improved on this approach by hiring single counsel to represent multiple defendants. ${ }^{100}$

These so-called Wellington negotiations also solved another problem encountered under the OAL Plan. Settlement and judgment dollars were generally paid by producers, multiple insurers, excess carriers, and reinsurers. Early in the asbestos litigation producers and insurers heatedly debated which parties bore the risk for asbestos-related injuries. ${ }^{191}$ Some focused on the time a plaintiff was exposed to asbestos, ${ }^{192}$ while others emphasized the time

100 Id. at 10 (categories were insulation cases, manufacturing products cases (e.g., plant workers), friction materials cases (e.g., brake repairers), asbestos and other materials cases (e.g., roofers), and employer defendant cases (e.g., intentional harm claims)).

${ }^{100}$ In situations where the claim cannot be resolved through the Asbestos Claims Facility or an ADR procedure, the Facility will defend any civil court litigation and will employ a single team of lawyers. Wellington, Asbestos: The Private Management of a Public Problem, 33 Clev. ST. L. Rev. 375, 388 (1984-85).

${ }^{191}$ See generally Note, Adjudicating Asbestos Insurance Liability: Alternatives to Contract Analysis, 97 HARv. L. Rev. 739, 739 (1984) ("Asbestos manufacturers and their insurers have been engaged in extensive litigation over whether the relevant products liability insurance policy. . . provides indemnification for the tort claims of the victims of asbestos-related diseases.") (footnote omitted).

${ }_{102}$ See, e.g., Porter v. American Optical Corp., 641 F.2d 1128, 1145 (5th Cir.), cert. denied sub nom. Aetna Casualty \& Sur. Co. v. Porter, 454 U.S. 1109 (1981) (same); Insurance Co. of N. Am. v. Forty-Eight Insulations, Inc., 633 F.2d 1212, 1218-23 (6th Cir. 1980) (upholding "exposure theory" over "manifestation theory"), modified, 657 F.2d 814, 816, cert. denied sub nom. Aetna Casualty \& Sur. Co. v. Porter, 454 U.S. 1109 (1981). 
the disease manifested itself. ${ }^{193}$ Circuit courts of appeals have sharply differed on this issue, ${ }^{194}$ but it had become moot in the Sixth Circuit prior to the creation of the OAL Plan. The Wellington negotiations created a common mechanism for producers and insurers to pay settlements.

Another equally serious insurance problem remained. The majority of general comprehensive insurance policies provided a defined sum of money to indemnify the insured producers for settlement and judgment costs, and an undefined sum to pay defense costs associated with protecting the insured in the litigation. ${ }^{195}$ This type of contractual relationship created a moral hazard. ${ }^{196}$ The producers had already paid premiums entitling them to a virtually infinite amount of defense costs associated with indemnity payments up to the limits of the primary policy. Therefore, their incentives were to force the insurers to spend those dollars in order to protect the finite amount of indemnity dollars purchased. Many primary insurers, on the other hand, recognized that they would eventually have to tender all of the indemnity dollars contracted for. Their incentives were to reduce the transaction costs associated with compensating plaintiffs for their injuries because once indemnity dollars were exhausted, they would no longer be obliged to pay defense costs. ${ }^{197}$ These disparate incentives created disparate defense strategies. To assist the parties in resolving their conflict, Judge Lambros brought insurance company representatives into the negotiation process. The Wellington agreement eventually accomplished the same goal by creating a defined method for its

${ }^{193}$ Eagle-Picher Indus. v. Liberty Mut. Ins. Co., 682 F.2d 12, 19-21 (1st Cir. 1982) (adopting the "manifestation theory" over the "exposure theory"), cert. denied, 460 U.S. 1028 (1983).

${ }^{124}$ In addition to the contrasting treatments by the 5th, 6th and 1st Circuits, the District of Columbia Circuit has adopted both theories in allowing for multiple triggers of coverage. Keene Corp. v. Insurance Co. of N. Am., 667 F.2d 1034, 1047 (D.C. Cir. 1981), cert. denied, 455 U.S. 1007 (1982). Despite the wide variance in holdings, the Supreme Court has declined to resolve the conflict.

${ }^{205}$ See Wellington, supra note 190, at 384 (citing cases supporting the asbestos producers' contention "that insurance policies written on forms developed before October 1966 provide a defense obligation that survives the exhaustion of indemnity limits").

100 See Pauly, Overinsurance and Public Provision of Insurance: The Roles of Moral Hazard and Adverse Selection, 88 Q.J. EcoN. 44 (1974); Shavell, On Moral Hazard and Insurance, 92 Q.J. EcoN. 540 (1979).

${ }_{187}$ Compare Keene Corp. v. Insurance Co. of N. Am., 597 F. Supp. 946, 950-54 (D.D.C. 1984) (insurer's duty is limited based on the pre-1966 policy language), with Commercial Union Ins. Co. v. Pittsburgh Corning Corp., 553 F. Supp. 425, 429-31 (E.D. Pa. 1981) (ambiguous policy language construed in favor of the insured). 
members to pay both defense and indemnity costs. ${ }^{198}$

Besides altering the configuration of existing parties, the OAL Plan expected the special masters and their assistants to act as neutral third parties, gathering and organizing information not otherwise available. The judge would also mediate between the parties, to seek areas for cooperation.

2. Issues. The OAL Plan neither expanded nor contracted issues. However, it divided issues into two categories and reconstituted the agenda for considering each category. ${ }^{198}$ In the first category were issues related to case evaluation. One of the masters concentrated on insuring that the minimal amount of discovery necessary for a threshold case evaluation was gathered first, ${ }^{200}$ including the total values of earlier similar cases. If the parties did not settle, then extensive discovery would be undertaken for trial.

The second category covered issues related to apportioning damages among defendants. ${ }^{201}$ The parties received information concerning the historic shares paid by each defendant in past trials and settlements. The Wellington negotiations obviated the need to develop these issues fully by undertaking separate negotiations to allocate responsibility among defendants using a system similar, but national in scope, to that proposed in the OAL Plan. ${ }^{202}$

3. Information. In addition to the normal kinds of evidence generated in litigation, the OAL Plan provided two types of information concerning case values: historic trial and settlement values, and summary jury trial values. Neutral third parties gathered data on over 300 variables for each completely resolved case. Data collection was performed by trained individuals completing a data collection protocol, and the data was entered into a computer for subsequent analysis. ${ }^{203}$ In conjunction with policy analysts, we created a decision support system to facilitate the parties' use of the

${ }^{103}$ See Wellington, supra note 190 , at 384-85 (usually this is a question of contract interpretation, but Wellington tried to sidestep litigating a tough issue by reaching a compromise between two polar positions).

190 The categories were "evaluation of claims" and "apportionment among defendants." Ohio Asbestos Litigation Case Management Plan and Case Evaluation and ApPORTIONMENT Process 113-20 (Dec. 16, 1983); see id. at 98-99 (sample agenda).

${ }^{200}$ Id. at 121-24.

201 Id. at 119-20.

${ }^{202}$ Based on data collected from their past litigation experience the asbestos producers developed a formula for allocating a liability share to every subscribing producer for all claims presented to the Asbestos Claims Facility. See Wellington, supra note 190, at 388.

${ }^{203}$ Ohio Asbestos Litigation, N.D. Ohio Case Management Plan and Case Evaluation and Apportionment Process 121-24 (Dec. 16, 1983). 
collected data through computer-assisted negotiation..$^{204}$

First, a case-matching program listed the data from a pending case, located the three cases that it most resembled, and indicated which characteristics did and did not match. ${ }^{205}$ Second, the parties could use a decision tree analysis to evaluate cases by folding back sequential estimates of outcomes on preliminary issues and ultimately reaching a single case value. ${ }^{208}$ Third, a mathematical model using standard statistical analysis was designed to incorporate the relative importance of the critical variables during a final case evaluation. ${ }^{207}$ Finally, an expert system was created to mimic the decisionmaking process of attorneys who evaluate cases. ${ }^{208}$

The case-matching program became the only operational form of assistance for the parties. ${ }^{208}$ Once the computer had produced the matching cases and their values, a hearing was held to discuss the pending cases. The parties could briefly state their analysis of each case, the matching cases were reviewed, and we estimated a settlement range from all this information. The settlement ranges generally varied between 10 and 20 percent, which was usually less than the transaction costs associated with trial. If both parties

204 Decision support systems make use of system dynamics and econometric models to increase the computer's role in the decisionmaking process. Such systems are effective to accommodate decisions which are both sufficiently structured to allow some form of modeling and yet still require the decisionmaker's less quantifiable judgment. See generally $\mathrm{R}$. Bonczek, C. Holsapple \& A. Whinston, Foundations of Decision Support Systems (1981); R. Sprague \& E. Carlson, Building Erfective Decision Support Systems (1982); Decision Support Systems: A Data-Based, Model-Oriented, User-Developed Discipline (W. House ed. 1983).

${ }^{205}$ See Mark A. Peterson, New Tools por Reducing Crvil Litigation Expenses 15 (1983) (if information has been gathered on prior settled and tried cases, proposed settlement values can be justified by references to similar resolved claims).

${ }^{200}$ For discussion of decision tree methodology, see Howard RaIfra, Decision AnalySIS: INTRODUCTORY LECTURES ON CHOICES UNDER UNCERTAINTY 10-38 (1968). For application in the legal arena, see Bodily, When should you go to court?, 59 HARv. Bus. REv., May-June 1981, at 103, 105-10.

${ }^{207}$ See M. PETERson, supra note 205, at 17-20.

${ }^{208}$ For example, the Rand Corporation has been developing two such expert systems: the Legal Decisionmaking System (assisting in the settlement of product liability cases) and the System for Asbestos Litigation (estimating how much money should be paid to claimants). Donald A. Waterman, A Guide to Expert Systems 268-69 (1986); see also Johnson, What Kind of Expert Should a System Be?, 8 J. MeD. \& PrIl. 77 (1983).

${ }^{200}$ In addition to the computer-assisted negotiation, Judge Lambros provided the parties an opportunity to obtain case evaluation information from summary jury trials. For a short description of the mechanics of summary jury trial, see Posner, The Summary Jury Trial and Other Methods of Alternative Dispute Resolution: Some Cautionary Observations, 53 U. CHI. L. REv. 366, 368-69 (1986); see also Lambros \& Shunk, The Summary Jury Trial, 29 Clev. ST. L. REv. 43 (1980); Lambros, The Summary Jury Trial and Other Alternative Methods of Dispute Resolution: A Report to the Judicial Conference of the United States Committee on the Operation of the Jury System, 103 F.R.D. 461 (1984). 
commenced negotiations within the suggested range, the chances of a settlement increased greatly.

\section{Results}

All 112 cases settled within 27 months of the implementation of the OAL Plan. All of the eventual settlements were within the special masters' range of predicted values.

1. Economy. At first glance, the OAL Plan appears enormously successful, but substantial problems cropped up in its implementation which deserve closer scrutiny. ${ }^{210}$ The cost for special masters, experts, computer runs, and other expenses of designing and implementing the OAL Plan during the three-year period was over $\$ 250,000$, although a major grant from the National Institute for Dispute Resolution softened the impact on the parties. The court's and parties' time expenditures were also substantial. Multiple separate negotiations took place, some persisting over extended periods of time. Forty-three OAL Plan orders have been promulgated by the court.

Although some savings were produced because no trials had to be held, everyone's opportunity costs were nevertheless substantial. A pending evaluation of the OAL Plan will attempt to make simplifying assumptions and suggest how the cost in time and money compares to more traditional litigation. In all probability, any economic justification for the OAL Plan would have to be made in terms of a capital investment. In other words, funds were invested to produce an asset which is not exhausted by a single use. This approach could be justified in part by the adoption of OAL Plan components in other jurisdictions, such as the Eastern District of Texas and the District of Massachusetts, and by the Wellington Plan. However, the individual plaintiffs, who absorbed some of the costs of the OAL Plan, would find the capitalization argument less persuasive.

A reduction in error costs may be the strongest argument for the OAL Plan. Virtually all plaintiffs who received settlements had long histories of asbestos exposure and had received a medical diagnosis of some asbestos-related disease. There were no false negatives in the OAL Plan-anyone who met the exposure and injury criteria received some compensation. There may have been a small

210 Judge Lambros has requested the author to work with a neutral study team to evaluate the overall merits of the OAL Plan. In addition, Professor Green and the author are writing an article about their experiences. 
number of false positives, but the rigorous entry criteria minimized them.

2. Fairness. An evaluation for fairness also gives mixed reviews. The plaintiffs and their attorneys generally seemed pleased that the cases were being resolved speedily, without full trials and expensive discovery. Defendants and their attorneys seemed less satisfied. They found the original OAL Plan overly complex, the constant revisions disconcerting, and the court's interventionist posture constraining on their ability to represent their clients as they saw fit. Defendants did not feel that the settlements were excessive, but that they had insufficient opportunity to prepare complete defenses. They believe that as product liability law has been applied to asbestos cases, plaintiffs have the advantage and defendants must engage in extensive discovery to prove that a person does not deserve compensation. Plaintiffs' attorneys have typically responded to these arguments by noting a propensity for defense counsel to churn cases and for defendants to hold on to their assets as long as possible. The ongoing evaluation should give a clearer picture of the reality behind these sentiments.

3. Other Values. Plaintiffs and their attorneys also appeared to appreciate being able to participate in the evaluation conferences and did not view the decision support system as impinging on their individual sense of worth. Defendants and their attorneys, on the other hand, preferred the more traditional methodology for resolving cases and felt that the court had partially usurped their usual case management prerogatives. As a result, they reacted negatively to losing control of the litigation.

A final, compelling argument in favor of the OAL Plan is its consistency with the underlying values of product liability law. Most states, including Ohio, have adopted strict liability in tort, thereby making it easier for plaintiffs to recover. Society, through its expression of tort law, has decided to accept a greater frequency of personal injury awards in order to heighten the incentives to manufacturers to produce safer products. Much of the defendants' criticism concerning the value of expediting the litigation process can be viewed as a basic disagreement with the policies underlying strict tort liability.

Judge Lambros had decided in 1982 that traditional litigation was biased toward inefficient dispute resolution, and had asked the special masters to design a management plan that would reduce that inefficiency while maintaining other due process values. Far more sophisticated analysis will be necessary to determine the relative merits of the OAL Plan and the traditional litigation model. 
In this instance the ex ante analysis of the OAL Plan may appear more favorable than an ex post one.

\section{Conclusion}

Flaws exist in our current litigation system. The thesis of this article is that overallegiance to traditional methods of dispute resolution can create substantial barriers to effective resolution of complex disputes. Judges and attorneys who use the same set of procedures in every case can anticipate less than satisfactory results. The issue raised here is whether acceptable alternatives to current practices can be applied without losing substantial values embedded in those practices.

Both the litigation management and ADR movements suggest that significant benefits can be achieved if judges and attorneys become active in tailoring procedures to meet the needs of individual disputes. The three cases discussed above illustrate how techniques can be adapted to a given dispute. Most of the innovations-computer-assisted negotiation, scorable game, appellate expert, and case evaluation decision support system-draw heavily on inquisitorial elements commonly associated with European justice systems and cooperative efforts found in negotiation. Yet nothing inherent in the descriptive analysis requires solely inquisitorial and cooperative changes. Equally important as these concrete proposals is the spirit of experimentation-a quest to find new methods of resolving disputes to improve the administration of justice. Yet this experimentation should be carefully monitored to ensure that no intermediate injustices are created, and must be painstakingly evaluated to determine when replication is advisable.

Notwithstanding the apparent success of the new case management techniques described above, there is still risk associated with any substantial deviation from accepted procedures. When are these risks worth taking? What specific criteria indicate how to apply any new techniques? What happens when these criteria conflict? These and similar questions cry out for a more systematic, principled approach to the management of complex cases. If the managerial horse is indeed out of the barn, we need a theory for managing the horsepower.

Such a theory should take into account not only the identifiable objective criteria of cases, but also a host of more subtle factors which may be just as important to the perceived legitimacy of our dispute resolution system. For example, some procedural innovations owe much of their success to an ability to change the way the participants in the litigation relate to one another. Among 
other effects, such techniques may alter the balance of power among the parties. An example of this would be if a special master, while streamlining discovery or facilitating settlement negotiations, innocently disclosed to a party information which seemed obvious to the master, yet which provoked an insight that the party would otherwise have missed. This relatively innocuous alteration in power effects can become more serious in light of recent findings in the behavioral literature regarding mediators. First, certain personality types seem to be peculiarly suitable for mediation. ${ }^{211}$ Second, a trait which often accompanies natural mediation ability is a desire for power. ${ }^{212}$ Therefore, precisely those persons who can be the most effective mediators may be most tempted to exercise power over the litigants, perhaps in subtle ways. Yet attempts to forestall abuses by constraining masters' discretion and flexibility may impede their effectiveness. ${ }^{213}$

It is suggested here that the descriptive literature on litigation management should be expanded by developing actual case histories. Unfortunately, most of the current literature consists of less than systematic anecdotal accounts. A consistent descriptive methodology is necessary to enable more sophisticated treatment. The analysis presented here focuses on the number and identity of the parties, the amount and nature of the information, the selection and ordering of the issues, and the behavioral patterns of the participants. Reasoning inductively from these descriptive analyses may assist the development of more principled methods of case management. The challenge for this and following articles, then, is to devise a general functional approach to managing complex litigation.

Based upon my experience in these cases, I argue that efforts to improve dispute resolution practices rather than limit access to the courts should be supported. Flexibility should be given to decisionmakers who, looking at a lawsuit ex ante, determine that reasonable men would agree that the net benefits from an alternative approach exceed those of the existing system. Armed with principles, methodology, exuberant skepticism, and an openness to pub-

${ }^{211}$ See Goleman, Influencing Others: Skills Are Identified, N.Y. Times, Feb. 18, 1986, at 15, col. 1 (national edition); see also Gurucharri \& Selman, The Development of Interpersonal Understanding During Childhood, Preadolescence, and Adolescence: A Longitudinal Follow-up Study, 53 CHmD Dev. 924 (1982).

212 Id.

${ }^{213}$ See McCrory, Environmental Mediation-Another Piece for the Puzzle, 6 VT. L. Rev. 49, 51 (1981); Stulberg, The Theory and Practice of Mediation: A Reply to Professor Susskind, 6 VT. L. REv. 85, 115-16 (1981). 
lic scrutiny, the movement toward managerial judging and alternative dispute resolution can assist our transition into the next era of the administration of justice. 